\title{
Ecological impacts of winter water level drawdowns on lake littoral zones: a review
}

\author{
Jason R. Carmignani ${ }^{1}$ - Allison H. Roy ${ }^{2}$
}

Received: 16 March 2017 / Accepted: 27 June 2017 / Published online: 6 July 2017

(C) The Author(s) 2017. This article is an open access publication

\begin{abstract}
Freshwater littoral zones harbor diverse ecological communities and serve numerous ecosystem functions that are controlled, in part, by natural water level fluctuations. However, human alteration of lake hydrologic regimes beyond natural fluctuations threaten littoral zone ecological integrity. One type of hydrologic alteration in lakes is winter water level drawdowns, which are frequently employed for hydropower, flood control, and macrophyte control, among other purposes. Here, we synthesize the abiotic and biotic responses to annual and novel winter water level drawdowns in littoral zones of lakes and reservoirs. The dewatering, freezing, and increased erosion of exposed lakebeds drive changes in the littoral zone. Shoreline-specific physicochemical conditions such as littoral slope and shoreline exposure further induce modifications. Loss of fine sediment decreases nutrient availability over time, but desiccation may promote a temporary nutrient pulse upon re-inundation. Annual winter drawdowns can decrease taxonomic richness of macrophytes and benthic invertebrates and shift assemblage composition to favor taxa
\end{abstract}

Electronic supplementary material The online version of this article (doi:10.1007/s00027-017-0549-9) contains supplementary material, which is available to authorized users.

Jason R. Carmignani

jcarmignani@eco.umass.edu

Allison H. Roy

aroy@eco.umass.edu

1 Organismic and Evolutionary Biology Program, University of Massachusetts, Amherst, MA 01003, USA

2 U.S. Geological Survey, Massachusetts Cooperative Fish and Wildlife Research Unit, Department of Environmental Conservation, University of Massachusetts, Amherst, MA 01003, USA with r-selected life history strategies and with functional traits resistant to direct and indirect drawdown effects. Fish assemblages, though less directly affected by winter drawdowns (except where there is critically low dissolved oxygen), experience negative effects via indirect pathways like decreased food resources and spawning habitat. We identify eight general research gaps to guide future research that could improve our understanding about the complex effects of winter drawdowns on littoral zone ecology.

Keywords Drawdown $\cdot$ Littoral zone $\cdot$ Macrophyte . Algae $\cdot$ Macroinvertebrate $\cdot$ Fish

\section{Introduction}

In lentic ecosystems, water level fluctuations create a natural disturbance regime that helps to structure the littoral zone (Gasith and Gafny 1990; Wantzen et al. 2008; Strayer and Findlay 2010). Seasonal and inter-annual water level fluctuations influence the survival of numerous flora and fauna in the littoral zone (Hill et al. 1998; Riis and Hawes 2002; White et al. 2008). High flows and flooding release nutrients from riparian areas (Baldwin and Mitchell 2000) and provide spawning habitat for numerous fish species (Kahl et al. 2008; Gertzen et al. 2012). Sediment dewatering and subsequent desiccation stimulates macrophyte species propagation and enhances nutrient cycling (Keddy and Reznicek 1986; Hill et al. 1998; Baldwin and Mitchell 2000). Through the interplay of direct (e.g., physiological stress) and indirect (e.g., habitat alteration) mechanisms, water level fluctuations create temporal and spatial heterogeneity that structures littoral zone communities (Hofmann et al. 2008). 
Although natural water level fluctuations are critical for ecosystem structure and function, hydrologic alterations in impounded lakes and river reservoirs (hereafter referred to as lakes) that exceed natural variability may be detrimental to lake ecosystems (Winfield 2004; Peters and Lodge 2009; Strayer and Findlay 2010). Hydrologic modification and concomitant habitat loss threaten ecosystem functioning and biodiversity in lakes (Stendera et al. 2012). Altered water level regimes include frequent, extreme fluctuations and water level stabilization, both that create novel environments (Boschilia et al. 2012).

In temperate and boreal regions, annual fall and winter water level drawdowns (hereafter: winter drawdowns) and subsequent spring refills (Fig. 1) are a common lake and reservoir management practice to achieve a variety of human goals. Increased energy demand lowers water levels in hydroelectric reservoirs during winter months (Aroviita and Hämäläinen 2008) and further provides storage in anticipation for seasonal spring flooding (Hellsten 1997). In recreational lakes throughout North America, annual winter drawdowns serve as a preventative measure to protect docks and retaining walls from ice scour damage, permit shoreline cleanup, and reduce nuisance levels of aquatic vegetation (Cooke et al. 2005). Historically, fishery managers used drawdowns to stimulate piscivorous sport fish populations by reducing prey refuge habitat, concentrating prey populations (Hulsey 1957; Lantz et al. 1967; Groen and Schroeder 1978), and promoting macrophyte growth for spawning and rearing refuge for these species (Fox et al. 1977). In addition, managers use drawdowns to attempt to eradicate undesired fish species (e.g., common carp) to promote clear water conditions (Verrill and Berry Jr. 1995).

Although the goals of winter drawdowns vary, comparison of responses of abiotic conditions and biotic assemblages to drawdowns across study systems can be useful in advancing the understanding of lake alteration. Despite an increase in research on water level fluctuations since the early 1990s, research on winter drawdowns remains limited and needs an updated synthesis. Recent review papers focus on the influence of regulated water level fluctuations on shallow lakes and wetlands (Coops et al. 2003), stratified lakes (Zohary and Ostrovsky 2011), lakes in general (Leira and Cantonati 2008), and alpine hydropower reservoirs (Hirsch et al. 2017). Previous reviews specific to winter drawdowns include Cooke (1980), Ploskey (1983), Wilcox and Meeker (1992), and most recently by Cooke et al. (2005) and Abrahams (2006) with a specific focus on macrophyte management. A comprehensive synthesis of winter drawdowns has not happened in the last 25 years.

Given the widespread use of winter drawdowns as a management tool, a current review is needed to update and centralize knowledge on impacts of drawdowns. Here, we synthesize the effects of winter water level drawdowns and subsequent spring refills on multiple components of the lake ecosystem. We describe responses of the physicochemical environment, macrophytes, algae, invertebrates, and fish, emphasizing the potential bottom-up cascading impacts. Lastly, we identify knowledge gaps and propose future research to advance the understanding of abiotic and biotic dynamics in response to winter drawdowns across a gradient of environmental conditions.

\section{Physicochemical changes}

\section{Sediment and Ice}

Littoral sediment patterns (i.e., grain size, soil water content, bulk density) are a function of wind/wave energy modified by lake morphometric measures including depth, slope, shoreline exposure, and fetch (Rowan et al. 1992; Blais and Kalff 1995; Hellsten 1997; Cyr 1998). In many deep lakes with steep shorelines, waves suspend fine sediment from littoral areas and deposit sediments into
Fig. 1 Water level time series of an annual winter drawdown lake (Goose Pond, Tyringham, Massachusetts) over two drawdown periods (2014-2016). Water level is expressed relative to median summer water levels. Grey triangles indicate initiation and cease of drawdown and refill phases

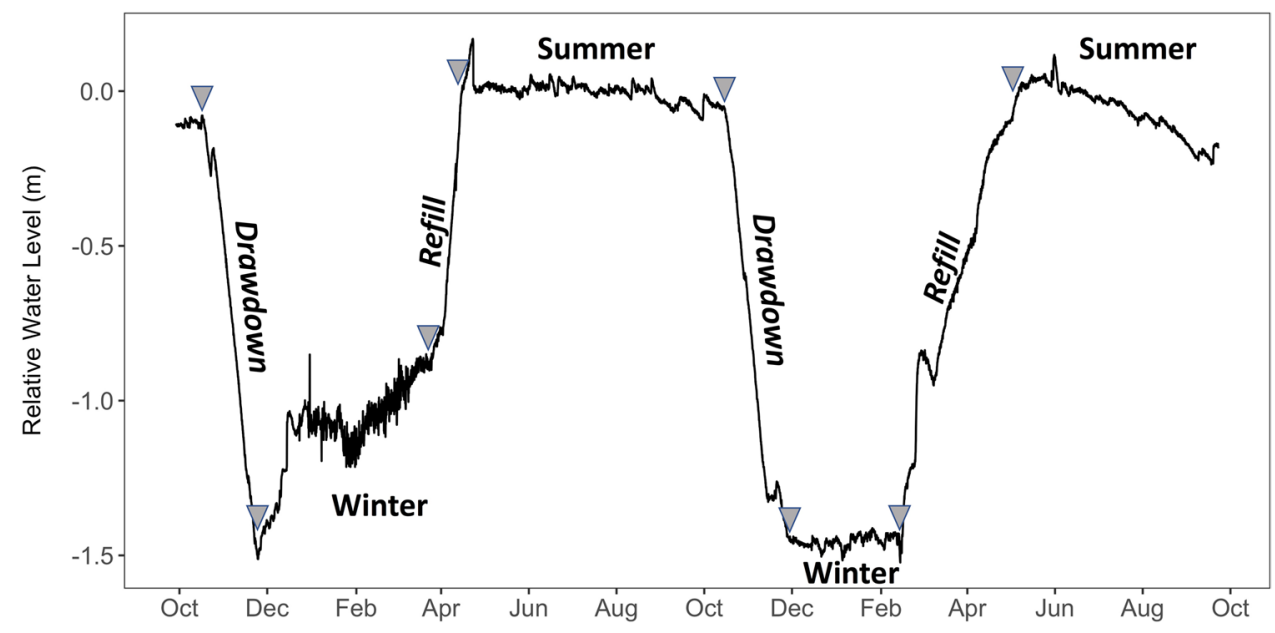


deeper areas (Håkanson 1977; Hellsten 1997; Cyr 1998). Drawdown can accelerate this sediment focusing process (Luken and Bezold 2000), whereby sediment coarsening occurs in the upper littoral zone and fine sediment deposition increases in the sublittoral and the profundal zones (Fig. 2, Hellsten and Riihimäki 1996; Wagner and Falter 2002; Effler and Matthews 2004; Furey et al. 2004), potentially leading to shallower lake profiles (Beklioglu et al. 2006). Sediment desiccation and erosion from precipitation and wind/wave action consolidate sediment in the drawdown exposure zone (Tarver 1980; Wagner and Falter 2002; Furey et al. 2004) and increase sediment bulk density (Gottgens 1994). Conversely, a reduction in drawdown amplitude in an annual drawdown system can promote the deposition of fine sediment back into previously exposed littoral area (Benson and Hudson 1975).

The rate of refill and shoreline slope influence shoreline erosion and sedimentation during spring refills (Alasaarela et al. 1989). Rapid refills can enhance shoreline erosion in deeper depths (Furey et al. 2004) and resuspend fine sediment into the water column, increasing turbidity especially in shallow areas (Hestand and Carter 1974). Strong winds and waves during refill can exacerbate the rate of erosion
(Luettich et al. 1990; Coops and Hosper 2002). Thus, a relatively low rate of water drawdown and refill may enhance erosion of shallow littoral areas by increasing the exposure time to wind/wave energy (Lorang et al. 1993). Shallow, gently sloping lakes show a less distinct sedimentation response to drawdowns (Hellsten 1997) because fine sediment is more susceptible to entrainment in these lakes (Havens et al. 2004; Shantz et al. 2004).

Winter drawdowns also increase the area of lake sediment exposed to desiccation, freezing, and snow cover (Hellsten 1997). In the absence of groundwater seepage and inlets, water depth is inversely related to desiccation potential and further modified by physical sediment characteristics (e.g., porosity, grain size). Compared to finer sediments (e.g., clay, silt), coarse sediments (e.g., sand, gravel) possess lower water content (Håkanson 1977) and retain less water under drying conditions (i.e., drawdown phase).

The extent of scour from ice in drawdown lakes is determined by climate and weather patterns, winter drawdown regimes, substrate size distributions, and surface and groundwater seepages, among other factors (Erixon 1981; Rørslett 1988; Hellsten 1997). Generally, the level of ice disturbance on submerged sediments is higher in drawdown

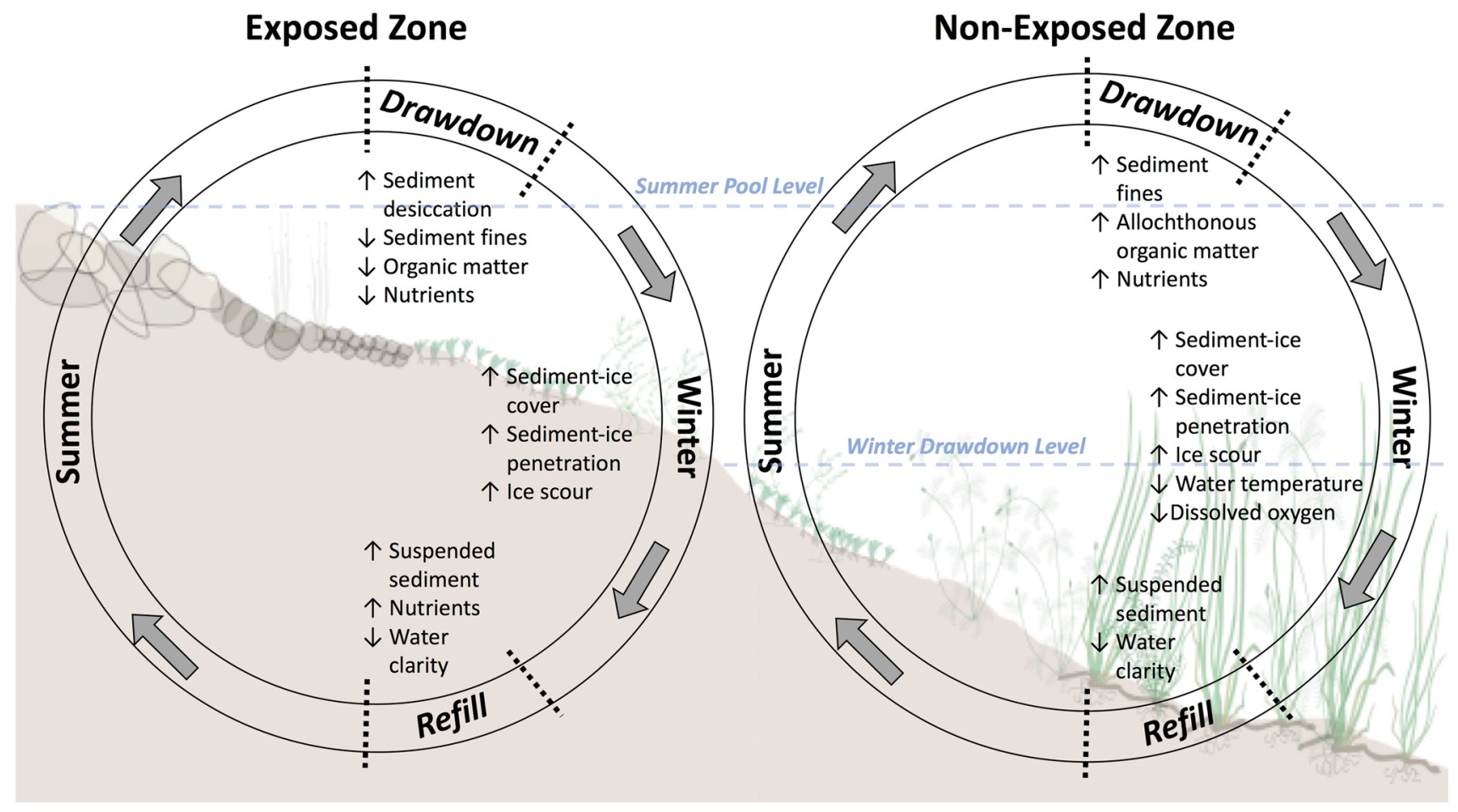

Fig. 2 Conceptual littoral zone profile of an annual winter drawdown lake. Circles represent abiotic patterns through time corresponding to water level drawdown, low winter water levels, and subsequent refill in exposed (left circle) and non-exposed areas (right circle) of the littoral zone. Background littoral zone represents theoretical depthspecific sediment and macrophyte character during summer given the summer pool and winter drawdown water levels (dashed lines). Macrophytes are generally reduced to low-growing (e.g., Elatine, Sagittaria) and seed-bearing species (e.g., Najas) in the exposure zone and sensitive species shift to deeper depths. Note that the level of erosion and macrophyte biomass loss is modified by littoral slope, photozone depth, and shoreline exposure to wind-wave action 
lakes compared to unregulated lakes (Rørslett 1984, 1988; Renman 1989; Palomäki and Koskenniemi 1993; Pugh and Davenport 1997; Hall et al. 1999). Where descending ice penetrates the sediment, needle ice can form causing frost heave (Renman 1989). Needle ice can also form on the surface of fine-grained sediment, particularly when sediment is moist (Renman 1993). In the deeper, non-frozen sediment zone, ice exerts mechanical pressure on the sediment surface (Hellsten 1997). In a hydroelectric lake in Finland, Hellsten (1997) found deeper ice-sediment penetration, larger area of ice, and longer durations of sedimentpenetrating and non-penetrating ice zones compared to an unregulated lake. Under zero to low snow cover, frozen sediment under drawdown is vulnerable to upheaval and subsequent transport to other areas of the lake upon refill (Mattson et al. 2004). However, snow cover can also insulate sediment, preventing freezing conditions and ice scour (Siver et al. 1986; Mattson et al. 2004). Furthermore, substrate composition modifies freezing patterns with sandy substrates most susceptible to freezing compared to finer and organic matter-rich substrates (Palomäki and Koskenniemi 1993; Hellsten 1997).

The timing of winter drawdowns relative to ice cover affects the location and extent of ice disturbance in lakes. Most studies on the distribution and cover of ice derive from Scandinavian countries, where ice cover can last for 5-8 months (e.g., Rørslett 1988; Renman 1993; Hellsten et al. 1996; Hellsten 1997). There, ice-on typically occurs before drawdown initiation, resulting in heavy ice scour at full pool levels and low drawdown water levels (Rørslett 1984, 1988). In contrast, ice-related disturbance in temperate climates likely result in ice scour in one location in the lake since drawdowns are initiated before ice-on and may not reach low drawdown water level before freezing conditions. Sediment desiccation is likely a more important stressor in temperate lakes.

\section{Nutrient dynamics}

Nutrient dynamics are altered in drawdown lakes compared to non-drawdown lakes based largely on the effect of drawdowns on sediment. Sediment coarsening and increased bulk density reduces the nutrient storage capacity (Barko and Smart 1986) and can further limit sediment-water nutrient flux via sediment burial in deeper areas (Fig. 2, Hall et al. 1999). The redistribution of organic and inorganic matter from littoral to deeper locations can result in a shift from autochthonous to allochthonous carbon (Gottgens 1994; Furey et al. 2004; McEwen and Butler 2010), likely resulting in changes to the composition, distribution, and densities of primary producers (e.g., benthic algae).

Regulated drawdowns may enhance the release of nitrogen and phosphorous from previously exposed sediment upon rewetting (Cooke 1980). In mesocosm experiments, nutrient release rates in dried and rewetted sediment can exceed the release rates under oxygenated submerged conditions for ammonium (Peverly and Kopka 1991; Qiu and McComb 1996; McGowan et al. 2005) and soluble reactive phosphorous (Qiu and McComb 1994; Steinman et al. 2012). Consequently, the nutrient pulse from reflooded sediments can temporarily increase nitrification (i.e., microbial activity) in aerobic conditions (Qiu and McComb 1996; Baldwin and Mitchell 2000; Corstanje and Reddy 2004). Upon reinundation, sediments located closest to the water-air interface (i.e., driest sediment) show the highest release of nutrients compared to deeper littoral depths (de Vicente et al. 2010; Steinman et al. 2012). Additionally, phosphorous can increase in both porewater and in the water column (Peverly and Kopka 1991). The main mechanisms of nutrient release include: (1) a reduced binding capacity of oxidized and desiccated mineral (e.g., iron, calcium, aluminum, manganese) phases (Qiu and McComb 1994; Baldwin 1996; Olilia et al. 1997; Watts 2000; Song et al. 2007; de Vicente et al. 2010; Steinman et al. 2012); (2) increased mineralization of organic phosphate and nitrogen (Qiu and McComb 1994; Olilia et al. 1997; James et al. 2001; Song et al. 2007; Steinman et al. 2009); (3) and microbial cell lysis (Qui and McComb 1995; Olilia et al. 1997; Mitchell and Baldwin 1998; Klotz and Linn 2001; Wilson and Baldwin 2008). Though system specific, these mechanisms of nutrient release depend on factors such as the size of the mineral resource pool (Jensen and Andersen 1992), the composition and desiccation tolerance of the microbial community (Baldwin and Mitchell 2000), the frequency and timing of drawdown and refill (Song et al. 2007; Wilson and Baldwin 2008), and the duration of drying (Olila et al. 1997).

The duration of sediment desiccation alters the chemical structure of phosphate-adsorbing minerals (e.g., iron). The initial phosphate adsorption capacity of oxidized sediment minerals is higher than submerged sediment (Baldwin 1996). However, with time (e.g., months), increasing oxidation and desiccation replaces high phosphate affinity amorphous mineral structures with low phosphate affinity crystalline structures, resulting in phosphate desorption (Baldwin 1996). After 0.5-1 years of lake sediment exposure, James et al. (2001) recorded a notable increase in phosphate-sediment release coincident with refill. Mineralization during sediment oxidation and desiccation contributes to nutrient pool availability for release upon inundation (James et al. 2001). Repeated cycles of sediment desiccation and rewetting also show higher phosphate release rates via mineralization and mineral desorption of phosphate compared to submerged conditions (Song et al. 2007). 
Few studies have examined the effect of winter drawdowns on changes of element and ion concentrations in water (Turner et al. 2005) and sediments (Peverly and Kopka 1991). Increases in calcium concentration is evident upon re-wetted conditions, as seen in soft-water lakes (Peverly and Kopka 1991; Turner et al. 2005). Other ions that show increases include silica (Turner et al. 2005) and potassium (Peverly and Kopka 1991), which in turn increase water alkalinity, conductivity, and $\mathrm{pH}$ levels.

\section{Dissolved oxygen and temperature}

Winter drawdowns also impact water-column dissolved oxygen (DO) levels. DO is naturally low in the winter via reduced photosynthesis, lower respiration demand, and lower atmosphere-water oxygen exchange (i.e., reduced wave action) due to snow and ice cover. Water volume loss with drawdowns also lowers DO concentrations during the winter months (Gaboury and Patalas 1984; Mills et al. 2002; Cott et al. 2008). In small ( $<30$ ha) and shallow lakes (maximum depth $<8 \mathrm{~m}$ ) of the Northwest territories, the DO during drawdown with low snow cover and ice thickness resemble DO under no drawdown with relatively thick snow and ice cover (Cott et al. 2008). DO will be higher in lakes with continuous groundwater or surface water inputs over lakes without continuous DO sources (Gaboury and Patalas 1984).

The effects of winter drawdown on water temperature vary with the regional climate and lake morphometry. Water temperature during winter drawdown can be within the natural variability in small boreal lakes (Cott et al. 2008). However, littoral zone depths that become relatively shallow during a winter drawdown can experience cooler than normal water temperatures. During an abnormally low winter water event in Lake Constance, Germany, Werner and Rothhaupt (2008) recorded sustained low water temperatures at depths rarely exposed to such low temperatures.

\section{Primary producer responses}

Macrophytes typically receive the most attention in studies that examine the effects of general water level fluctuation on the littoral zone (Leira and Cantonati 2008). In contrast, winter drawdown studies more equally cover macrophytes, invertebrates, and fishes (Fig. 3, Supplementary Appendix 1,2). Patterns of macrophyte distribution, community

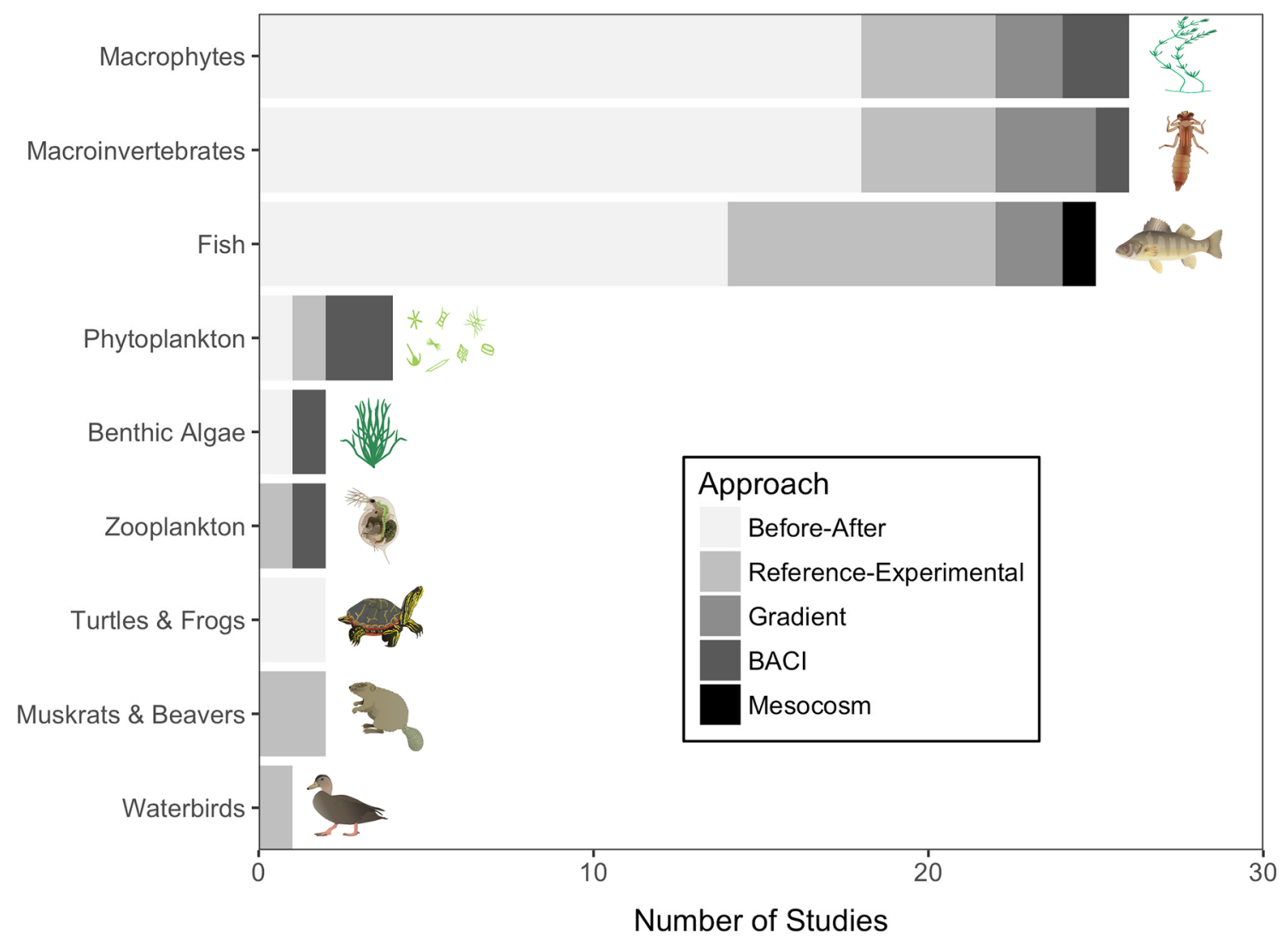

Fig. 3 Biotic responses variables from 73 winter drawdown studies color-coded by study approach 
composition, and abundance are primarily determined by abiotic factors such as organic matter content (Koch 2001), wind/wave exposure (Riis and Hawes 2003), temperature, light, sediment characteristics (i.e. texture, cohesion, stability, moisture content), and nutrient levels (Bornette and Puijalon 2011). Drawdowns modify these abiotic conditions, indirectly regulating macrophyte assemblages (Hill et al. 1998; Bornette and Puijalon 2011). Sediment desiccation and freezing exert direct mechanical disturbance and physiological stress on vegetative root structures (Siver et al. 1986). Subsequent spring refills can erode frozen sediment and displace plants (Beard 1973; Mattson et al. 2004). In soft-water systems drawdowns can stifle species growth by increasing acidity and cations (zinc, manganese) to toxic concentrations (Peverly and Kopka 1991). In contrast, the potential release of limiting nutrients upon refill may enhance primary production at least temporarily (Cooke 1980). Over time, annual winter drawdowns coarsen sediment texture and remove nutrients in the exposure zone often rendering it unsuitable for macrophyte colonization and growth, especially in more steep-sided basins (Hellsten 1997). Depths beyond the exposure zone are enriched with organic matter and sediment-adsorbed nutrients potentially inhibiting plant growth (Hellsten et al. 1996). Macrophyte responses to winter drawdown further depends on species' tolerance, life-history strategy, and growth plasticity, as described in more detail below.

\section{Macrophyte density and biomass}

Studies have documented reduced macrophyte density, biomass, and \% cover in the drawdown exposure zone compared to reference systems or previous non-drawdown conditions (Fig. 3, Tarver 1980; Wagner and Falter 2002; Turner et al. 2005; Beklioglu et al. 2006; Sutela et al. 2013). Annual drawdowns of relatively large amplitude (e.g. >2-3 m) significantly reduce density and biomass (Rorslett 1989; Turner et al. 2005; Keto et al. 2006; Sutela et al. 2013). Relatively mild drawdowns show less impact on macrophyte density, but decreases are apparent (Keto et al. 2006). Shallow and exposed water depths typically experience the strongest density declines due to atmospheric exposure and sediment desiccation (Thomaz et al. 2006). After a novel winter drawdown (1.2-m amplitude) in a Vermont lake/deep marsh system that exposed $13 \%$ of the sediment, 18 of 30 submergent and emergent macrophyte species in the deep marsh and 7 species in the lake portion showed significant decreases in cover and stem density (VANR 1990). Moreover, average surface plant cover and submerged plant cover decreased by $80 \%$ in the marsh and $46 \%$ in the lake (VANR 1990). Generally, macrophyte colonization and growth occurs in areas that remain wet year-round. Olson et al. (2012) found that winter drawdown amplitude corresponds with the shallow depth distribution of the invasive Myriophyllum spicatum (Eurasian water milfoil), and increased abundance with water depth. Similarly, McGowan et al. (2005) demonstrated higher biomass at depths greater than the drawdown amplitude. The extent of macrophyte biomass below the drawdown exposure zone depends on species-dependent thresholds of light and physicochemical sediment properties (Wagner and Falter 2002).

Re-colonization of the drawdown exposure zone from deep residing individuals can occur during the growing season if suitable growing conditions exist (VANR 1990; Turner et al. 2005; Thomaz et al. 2006; Olson et al. 2012). Species persistence in the exposure zone ultimately depends on the drawdown frequency and the species response to desiccation, freezing, and accelerated erosion. Reductions in winter drawdown amplitude can increase macrophyte biomass in newly submerged depths. For example, after a reduction in the amplitude of an annual drawdown regime, Wagner and Falter (2002) documented an increase in mean macrophyte biomass at depths shallower than the historical drawdown amplitude.

\section{Macrophyte richness and composition}

Assemblage composition is a function of the hydrological components of the drawdown regime (e.g., frequency, duration, and amplitude), competitive interactions, and the species-level tolerance to drawdown-related disturbance (e.g., desiccation, low temperatures, erosional forces). Seasonal water level fluctuations and inter-annual fluctuations together structure spatio-temporal assemblage composition and richness (Hill et al. 1998; Casanova and Brock 2000). As a result, macrophyte composition across winter drawdown lakes varies by depth with dissimilarities most pronounced in the eulittoral (Rørslett 1989; Hall et al. 1999; Turner et al. 2005) or sublittoral zone (Wilcox and Meeker 1991; Hellsten et al. 1996).

In annual winter drawdown systems, distinct assemblage compositions develop relative to reference systems (Wilcox and Meeker 1991; Sutela et al. 2013). Large amplitude drawdowns decrease species richness (Wilcox and Meeker 1991; Hellsten et al. 1996) with the potential loss of entire macrophyte assemblages if amplitudes are extreme (Rørslett 1989). In contrast, relatively intermediate amplitudes facilitate high macrophyte richness (Wilcox and Meeker 1991; Van Geest et al. 2005; Mjelde et al. 2012). For example, in numerous floodplain lakes of the lower Rhine River, Van Geest et al. (2005) recorded higher submergent species richness in lakes with drawdowns of 0.4-0.6 m compared to amplitudes of $<0.2 \mathrm{~m}$. Similarly, Mjelde et al. (2012), found a positive correlation of species richness and drawdown amplitude in Scandinavian lakes with water level amplitudes $<1.5 \mathrm{~m}$. 
Table 1 Macrophyte, macroinvertebrate, and fish traits that are sensitive (unshaded) or tolerant (shaded) to winter drawdowns. Traits include functions, life history characteristics, and habitat preferences. Example taxa and key literature sources are included

\begin{tabular}{|c|c|c|c|c|}
\hline Assemblage & & Trait & Taxa Examples & Source \\
\hline \multirow{6}{*}{ 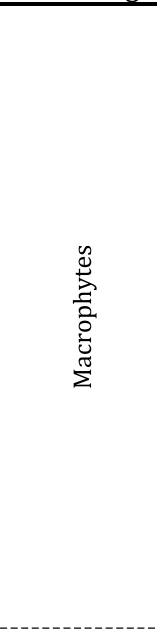 } & \multirow[t]{2}{*}{ Sensitive } & $\begin{array}{l}\text { Submergent species that propagate mostly by } \\
\text { rhizomes (perennials); low propagation via } \\
\text { seeds }\end{array}$ & $\begin{array}{l}\text { Potamogeton robbinsii } \\
\text { Myriophyllum spicatum } \\
\text { Nuphar lutea }\end{array}$ & $\begin{array}{l}\text { Beard et al. 1973; VANR 1990; Wilcox } \\
\text { and Meeker 1991 } \\
\text { Siver et al. 1986; Olson et al. } 2012 \\
\text { Beard et al. 1973; VANR 1990; Hellsten } \\
\text { 2000; Mjelde et al. } 2012\end{array}$ \\
\hline & & Sensitive to ice scour & $\begin{array}{l}\text { Isoetes lacustris (i.e., large } \\
\text { Isoetids) }\end{array}$ & $\begin{array}{l}\text { Rorslett 1984; Turner et al. 2005; Keto } \\
\text { et al. 2006; Mjelde et al. } 2012\end{array}$ \\
\hline & \multirow{4}{*}{ Tolerant } & High seed/oospore production & $\begin{array}{l}\text { Najas flexilis } \\
\text { Chara sp. }\end{array}$ & $\begin{array}{l}\text { Turner et al. } 2005 \\
\text { Wagner and Falter } 2002\end{array}$ \\
\hline & & Amphiphytic \& polymorphic growth forms & Eleocharis acicularis & $\begin{array}{l}\text { Wilcox and Meeker 1992; Hellsten 2000; } \\
\text { Mjelde et al. } 2012\end{array}$ \\
\hline & & Fast growth & Elodea sp. & Wagner and Falter 2002 \\
\hline & & Multiple viable propagation strategies & $\begin{array}{l}\text { Potamogeton spirillus, } P \text {. } \\
\text { epihydrus }\end{array}$ & Turner et al. 2005 \\
\hline \multirow{8}{*}{ 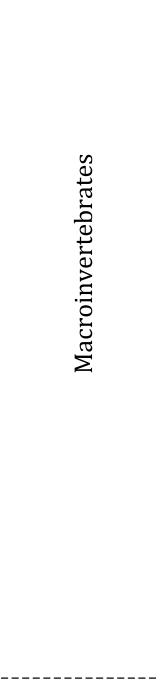 } & \multirow{4}{*}{ Sensitive } & Semivoltine & $\begin{array}{l}\text { Hexagonia sp., Oulimnius } \\
\text { tuberculatus, Sialis sp. }\end{array}$ & Aroviita and Hämäläinen 2008 \\
\hline & & \multirow{2}{*}{$\begin{array}{l}\text { Low to moderate mobility (i.e., clams and } \\
\text { crawlers) }\end{array}$} & $\begin{array}{l}\text { Elmidae, Hydrobiidae, } \\
\text { Psephenidae }\end{array}$ & White et al. 2011 \\
\hline & & & Asellus sp. & Grimås 1961; Kraft 1988 \\
\hline & & Fine-sediment burrowers & $\begin{array}{l}\text { Caenis sp., Hexagonia sp., } \\
\text { Sialis sp. } \\
\text { Ephemera vulgata }\end{array}$ & $\begin{array}{l}\text { Benson and Hudson 1975; Kraft 1988; } \\
\text { McEwen and Butler } 2010 \\
\text { Aroviita and Hämäläinen } 2008\end{array}$ \\
\hline & \multirow[t]{4}{*}{ Tolerant } & Moderate to fast mobility (i.e., swimmers) & $\begin{array}{l}\text { Talitridae, Dyticidae, } \\
\text { Corixidae }\end{array}$ & White et al. 2011 \\
\hline & & Multivoltine to univoltine & Chironomidae, Amphipoda & Kraft 1988 \\
\hline & & Fully aquatic life cycle & Amphipoda & McEwen \& Butler 2010 \\
\hline & & Physiological tolerance to freezing & Chironomus, Glyptotendipes & $\begin{array}{l}\text { Grimäs 1965; Paterson and Fernando } \\
\text { 1969; Koskenniemi } 1994\end{array}$ \\
\hline \multirow{8}{*}{$\frac{n}{5}$} & \multirow{5}{*}{ Sensitive } & Littoral spawning in the fall & Coregonus & $\begin{array}{l}\text { Gaboury and Patalas 1984; Sutela et al. } \\
\text { 2002; Mills et al. } 2002\end{array}$ \\
\hline & & Littoral spawning in the spring & Esox spp. & $\begin{array}{l}\text { Wegener and Williams 1975; Kallemeyn } \\
\text { 1987b; McDowell } 2012\end{array}$ \\
\hline & & Littoral juvenile life stage & Lota lota & Fischer and Öhl 2005; Sutela et al. 2011 \\
\hline & & \multirow[t]{2}{*}{ Insectivorous } & $\begin{array}{l}\text { Ameiurus nebulosus } \\
\text { Lepomis gibbosus }\end{array}$ & Haxton and Findlay 2009 \\
\hline & & & Cottus poecilopus & Sutela et al. 2011 \\
\hline & \multirow{3}{*}{ Tolerant } & Opportunistic feeders & Catostomus commersonii & McAfee 1980; Haxton and Findlay 2009 \\
\hline & & Pelagic feeders & Sander vitreus (juveniles) & Haxton and Findlay 2009 \\
\hline & & Habitat generalists & Catostomus commersonii & Haxton and Findlay 2009 \\
\hline
\end{tabular}

The annual frequency of winter drawdowns can establish a drawdown-tolerant assemblage (Nichols 1975). Even after 2-3 annual winter drawdowns, tolerant species can become the dominant species throughout the drawdown exposure zone (Beard 1973; Turner et al. 2005). Annual deep (e.g., >2-3 m) winter drawdowns support the development of macrophyte assemblages mainly composed of species with ruderal or semi-ruderal (e.g., stress-ruderal, 
competitive-ruderal) life history strategies and species that are polymorphic, amphiphytic, and/or free-floating (Table 1, Rørslett 1989; Hellsten 2002; Turner et al. 2005; Mjelde et al. 2012). Ruderal species, characterized as fast growing with early reproduction and a high annual seed production (Grime 1977; Rørslett 1989), tend to have multiple propagating strategies to increase the likelihood of individual persistence and population viability (Tazik et al. 1982; Siver et al. 1986). For example, winter buds or turions removed by erosion or thwarted by physiological stress can propagate from resistant seed banks or unspecialized vegetative fragments (Combroux and Bornette 2004). The viability of seed banks can last for multiple years until suitable germination conditions arise (Howard and Wells 2009). Generally, sediment desiccation stimulates seed germination (Keddy and Reznicek 1986) and facilitates propagation in the drawdown exposure zone (McGowan et al. 2005). Rising water temperatures and concomitant ice-off in the spring promote rapid growth and establishment of ruderal species, limiting growth of other macrophyte species (Wagner and Falter 2002). With increasing lake bed desiccation intensity and frequency, species that produce sexual diaspores or seeds (e.g., Najas minor, Potamogeton pectinatus) are expected to dominate assemblages (Bornette and Puijalon 2011; Arthaud et al. 2012). Species that are polymorphic or amphiphytic (e.g., Eleocharis acicularis, Ranunculus reptans) can tolerate erosion and sediment dewatering, enabling them to persist in drawdown lakes (Wilcox and Meeker 1992; Mjelde et al. 2012). Further, the likelihood of persistence for drawdown-tolerant taxa increases because of reduced competition (i.e., for nutrients, light, space) with reduced or extirpated drawdown sensitive species (Hellsten 2000; Boschilia et al. 2012).

While drawdown favors ruderal and polymorphic species, other macrophyte species are restricted to low densities or are extirpated (Table 1). Taxa most vulnerable in the drawdown exposure zone include perennial species (e.g., many Potamogeton spp.) that rely heavily on rhizomic structures (e.g., thallus) for propagation (Siver et al. 1986), obligate-submergent species (Thomaz et al. 2006; Boschilia et al. 2012), and species sensitive to ice scour (Hellsten 2002) For example, large isoetids (e.g., Isoetes lacustris, Lobelia dortmanna), highly sensitivity to freezing and ice-scour, show consistent declines and low abundances in boreal winter drawdown lakes (Hellsten 2002; Mjelde et al. 2012).

\section{Phytoplankton and alternative stable states}

Studies on the effects of winter drawdowns on phytoplankton, not only are few, but also show contrasting results. Limited evidence supports the prediction that phytoplankton blooms would increase upon sediment re-flooding because of potential nutrient pulses (Cooke 1980). Under a novel drawdown, seasonal climate more likely controlled phytoplankton densities and assemblage composition over water level variation (McGowan et al. 2005). Similarly, Turner et al. (2005) found no differences in phytoplankton biomass and photosynthetic rates after a series of drawdowns compared to reference lakes; but did find a small reduction in taxonomic diversity in the drawdown lake potentially due to a large lake bed exposure area. In a hydroelectric reservoir in Finland, Vuorio et al. (2015) found a positive correlation between the biomass and presence of the diatom Aulacoseira islandica on stationary fishing nets and above average drawdown amplitude and associated water release. Stronger currents generated by higher amplitudes and water release are likely responsible for increased diatom suspension in the water column even under ice cover. Little is known about the effect of winter drawdown on harmful cyanobacteria blooms (Bakker and Hilt 2016). Nõges and Nõges (1999) found that low winter and summer water levels enhanced light conditions and increased susceptibility to phosphorous via sediment resuspension, enabling cyanobacteria proliferation, but no studies have shown blooms with just winter drawdowns.

Seasonal drawdowns can transform shallow, eutrophic ecosystems from a clear-water, macrophyte-rich state to a turbid, phytoplankton-dominated state (Blindow 1992). However, little study exists on the influence of winter drawdowns on clear- and turbid-water states. A rapid refill can increase turbidity, reduce light penetration, and decrease macrophyte survival, growth, and recruitment (Hestand and Carter 1974). Macrophyte cover loss can increase sediment resuspension, reducing water clarity, which further inhibits macrophyte growth. A significant loss of submerged macrophyte cover from a winter drawdown, in combination with a pulse of limiting nutrients into the water column upon refill, can stimulate phytoplankton and cyanobacteria growth resulting in spring and summer blooms (Cooke 1980). High phytoplankton concentrations reduce light attenuation and favor macrophyte species tolerant to low-light conditions, such as free-floating or rooted floating species (Hestand and Carter 1974; Arthaud et al. 2012). In floodplain lake systems, shallow drawdowns (0.4-0.6 m) enhanced the development of transient submerged macrophyte assemblages before ultimately returning to a stable turbid state (Van Geest et al. 2007). The magnitude, frequency, and timing of drawdowns may influence whether a shallow, eutrophic lake will shift from a clear to turbid state.

\section{Benthic algae}

The depth gradient and associated substrate and light environment in part drive benthic algal assemblages (Cantonati 
and Lowe 2014), with water level fluctuations as a primary disturbance that can select for desiccation-tolerant benthic algae and cyanobacteria in littoral zones (Cantonati et al. 2009, 2014). Despite their central role in littoral zones and lake ecosystems, benthic algae are understudied in response to winter drawdowns and, where studied, periphyton show mixed responses. Turner et al. (2005) found no significant effect of three consecutive winter drawdowns on periphyton biomass, composition, and metabolism. The lack of periphyton response may be explained by rapid algal turnover rates and increases in algae associated with nutrient pulses offsetting potential reductions from substrate losses. Furthermore, frequent water level fluctuations can favor mobile benthic algae (Evtimova and Donohue 2016), with the potential to adapt to annual winter drawdowns systems (Turner et al. 2005). Sediment desiccation and freezing can promote taxa with spores resistant to these stresses. For example, species from the macroalgal genus Chara can proliferate via desiccation and freezing resistant oospore sediment banks (Havens et al. 2004), dominating the drawdown exposure zone during spring and summer months (Wagner and Falter 2002). Benthic algae grow on a variety of substrates that include macrophytes, wood, and a range of sediment textures (Vadeboncoeur and Steinman 2002), which differ in substrate-specific algal productivity (Vadeboncoeur et al. 2006). Where winter drawdowns decrease macrophytes and fine sediment, it is possible that epiphytic, epipelic, and episammatic algae will be reduced. In contrast, epilithic and epixylic algal species may benefit from sediment coarsening associated with drawdowns. The potential for periphyton assemblages to shift to less palatable taxa is unknown, and requires more study to detect cascading impacts in lake trophic structures.

\section{Benthic invertebrate responses}

Benthic invertebrate taxa distribution and abundance are largely determined by the spatio-temporal hierarchy of habitat and resource heterogeneity of the littoral zone (Heino 2008; Tolonen and Hämäläinen 2010). Significant environmental factors that influence littoral zone invertebrate distribution and abundance include lake morphometry (Palomaki and Hellsten 1996; Scheifhacken et al. 2007), benthic algae distribution and availability (Devlin et al. 2013), macrophyte density/biomass, substrate physical characteristics (e.g., texture, stability, physical complexity), and organic matter (Weatherhead and James 2001; Brauns et al. 2008; Free et al. 2009). Winter drawdowns interact with these lake-wide and local environmental parameters to indirectly structure benthic invertebrate assemblages (Scheifhacken et al. 2007; White et al. 2008, 2010; Evtimova and Donohue 2016). For example, the coarsening of exposed substrates and associated declines in macrophyte biomass and changes in macrophyte composition can respectively decrease and alter benthic and phytophilous invertebrate density and composition (Wilcox and Meeker 1992). Winter drawdowns directly influence benthic invertebrates in the drawdown exposure zone via stranding (Benson 1973) and increased exposure to desiccation and freezing above and within the sediment (Grimås 1961, 1965; Paterson and Fernando 1969; Palomaki and; Koskenniemi 1993; Scheifhacken et al. 2007; Haxton and Findlay 2008). Winter drawdowns also directly intensify physiological stress, particularly for relatively immobile taxa (e.g., bivalves) by exposing invertebrates to cooler water temperatures (Werner and Rothhaupt 2008).

\section{Density}

Winter drawdowns tend to reduce benthic invertebrate density in the exposure zone. In an analysis of ten studies, Haxton and Findlay (2008) found a large negative effect size of reservoir dewatering on littoral zone macroinvertebrate density. Other studies also found that biomass and density are often lowest in lakes with large (e.g. $>3 \mathrm{~m}$ ) drawdown amplitudes (Grimås 1965). However, at relatively low amplitudes, impacts of drawdowns on invertebrate density may be limited. For example, Delong and Mundahl (1995) found significant reductions in invertebrate densities in littoral zones after a $4.6 \mathrm{~m}$ drawdown; however, in the same lake 16 years later, Swanson (2010) found no significant density reductions at 0.6 and $1.5 \mathrm{~m}$ depths shortly after a $0.9 \mathrm{~m}$ winter drawdown. Under these amplitudes, other environmental factors (e.g., lake morphometry, local-habitat features, water quality) may better explain variation of assemblage level character (McAfee 1980; White et al. 2011). Despite the level of drawdown amplitude, invertebrate densities can remain similar across winter drawdown lakes at exposed and unexposed depths (Aroviita and Hämäläinen 2008). Invertebrate mortality from exposure can differ between substrates, with higher mortality on sand substrates compared to silt and organic substrates (Palomäki and Koskenniemi 1993; Koskenniemi 1994) and leaf litter potentially serving as refuge (Delong and Mundahl 1995). By late summer (i.e., several months after refill) most invertebrates have fully recolonized and exhibit similar densities between drawdown and non-drawdown lakes in the exposure zone (Aroviita and Hämäläinen 2008; Swanson 2010), with lag time inversely related to depth (Kraft 1988). In fact, after heavy assemblage mortality from desiccation and freezing, the survival or addition of opportunistic and tolerant species (e.g., Glyptotendipes barbipes) can produce a higher standing crop of invertebrates than the pre-drawdown level in the subsequent growing season (Paterson and Fernando 1969; Fiske 1989). 


\section{Richness and composition}

Annual winter drawdowns that exceed natural water level fluctuations tend to reduce benthic invertebrate richness and alter composition relative to unregulated lakes (Kraft 1988; Aroviita and Hämäläinen 2008; White et al. 2011). For example, in the Boreal Shield Ecozone where natural water level fluctuations are $<2 \mathrm{~m}$, White et al. (2011) found invertebrate taxa richness reduced at $\sim 2 \mathrm{~m}$, assemblage composition altered at 2-3 $\mathrm{m}$, and functional composition shifts at amplitudes $>3 \mathrm{~m}$. Benthic invertebrate richness and assemblage composition in lakes with relatively moderate drawdown amplitudes (e.g., 1.5-3 m) show varying responses compared to naturally fluctuating or semi-regulated lakes (Aroviita and Hämäläinen 2008 versus; White et al. 2011). Also, taxa richness may recover in late summer (e.g., August) at exposed drawdown depths before the next annual drawdown (Kraft 1988).

Species' resilience and sensitivity to winter drawdowns is related to their life history strategies, functional traits (e.g., swimming ability, feeding), and habitat preferences (Table 1). Generally, annual drawdown conditions impact invertebrates with longer generation times more than those with shorter life cycles (Koskenniemi 1994; McEwen and Butler 2010). Semi-voltine taxa (e.g., Hexagonia spp., Oulimnius tuberculatus, Ephemera vulgata, Limnius volckmari, Sialis spp.) are found in low numbers in winter drawdown lakes, presumably because larval stages experience the disturbance and stress of multiple drawdown events (Benson and Hudson 1975; Aroviita and Hämäläinen 2008).

Annual drawdowns of moderate to high amplitude (e.g., 2-3 m) promote opportunistic species with r-selected life history strategies (Benson and Hudson 1975; Kaster and Jacobi 1978; Septhton and; Paterson 1986). Rapid growth and reproduction upon inundation of the exposure zone are highly advantageous traits in frequently disturbed conditions. For example, chironomids possess short generation times with multiple generations per year, enabling these invertebrates to avoid inhospitable conditions associated with drawdown (Fillion 1967; Koskenniemi 1994; McEwen and Butler 2010). Other taxa characteristic of annual drawdown regimes includes amphipods (Smagula and Connor 2008), oligochaetes (Grimås 1965; Kaster and Jacobi 1978), and ceratopogonids (Benson and Hudson 1975; McEwen and Butler 2010). These invertebrates can physiologically tolerate freezing and burrow in sediment to inhabit relatively unaffected substrates (Grimås 1965; Patterson and Fernando 1967; Kaster and Jacobi 1978). These taxa tend to dominate the biomass in heavily regulated annual systems (Grimås 1965; McEwen and Butler 2010), particularly in shallow reservoirs with unstable sediments (Sephton and Paterson 1986).
Receding water levels during a drawdown favor fastswimming invertebrate taxa (White et al. 2011). Consequently, relatively immobile taxa are most susceptible to experiencing drying and freezing conditions. White et al. (2011) found significantly fewer crawlers (e.g., Elmidae with moderate mobility) and bivalves (e.g., clams with low mobility) in reservoirs with relatively high drawdown amplitudes $(>3 \mathrm{~m})$ compared to more mobile taxa (e.g., Talitridae, Dyticidae, Corixidae). Bivalve and gastropod populations are particularly vulnerable to drawdowns because of their slow and sometimes undirected movement (Samad and Stanley 1986) and slow re-colonization rates (Fiske 1989). Samad and Stanley (1986) showed the mussel species Elliptio complanata and Lampsilis radiata moved randomly before burrowing in response to receding water levels in a Maine lake, and Kaster and Jacobi (1978) observed many Lasmigona complanata mussels moving landward during water recession. Bivalves burrow to lessen the effects of exposure; however, weeks to months of dry and freezing conditions likely lead to mortality (Samad and Stanley 1986; Werner and Rothhaupt 2008). A single winter drawdown of sufficient amplitude with a long exposure time can result in mass mortality (Samad and Stanley 1986; Werner and Rothhaupt 2008). The impact on these sensitive species will vary with drawdown amplitude (i.e., exposure zone) relative to species distribution in the littoral zone.

\section{Distribution}

Water level fluctuations can strongly determine benthic invertebrate zonation (Gathman and Burton 2011) by influencing habitat availability and condition (Baumgärtner et al. 2008). Under natural water level fluctuations, the benthic invertebrate density generally decreases with depth, with the highest densities in shallow depths found in the upper littoral zone (Grimås 1961; Kaster and Jacobi 1978). Invertebrate species limited to the upper littoral are most vulnerable to wintertime low water events (Brauns et al. 2008). The maximum benthic invertebrate density or biomass in spring and summer months shift to depths below the exposure zone (Grimås 1961; Fillion 1967; Benson and Hudson 1975; Kaster and Jacobi 1978; Kraft 1988; Palomäki and Koskenniemi 1993; Palomäki and Hellsten 1996; Furey et al. 2006; Sheifhacken et al. 2007). The shift corresponds to the distribution of food resources (e.g., and organic matter), suitable habitat, and mortality (Fillion 1967; Palomäki 1994; Palomäki and Hellsten 1996; Furey et al. 2006). However, invertebrates resistant to freezing (e.g., Chironomus, Glyptotendipes) can withstand exposed conditions and reemerge in the spring from recently exposed substrates in high abundance, showing comparable depth distributions as in naturally fluctuating lakes 
(Koskenniemi 1994; Delong and Mundahl 1995). Similarly, Aroviita and Hämäläinen (2008) did not find any taxa indicative of winter drawdown lakes at upper and lower littoral zones across a gradient of amplitudes.

\section{Fish responses}

The littoral zone provides spawning habitat, young of year (YOY) refuge habitat (Winfield 2004), rich benthic algae and invertebrate food resources (e.g., Vadeboncoeur et al. 2002; Vander Zanden et al. 2011), and physically complex habitat (e.g. macrophytes, coarse woody debris) that mediates competition and predation (Diehl 1988; Savino and Stein 1989; Beauchamp et al. 1994; Lewin et al. 2004). For example, macrophyte assemblages offer a variety of meso- and microhabitats including transient heterogeneous DO and temperature refugia (Miranda et al. 2000) that can harbor distinct fish size-classes (Chick and McIvor 1994; Yamanaka 2013), high fish densities (Keast 1978; Hugh Barwick 2004; Randall et al. 2012), and high species richness (Keast 1978; Pratt and Smokorowski 2003; Hugh Barwick 2004) compared to other littoral mesohabitats. Declines in fish diet, growth rate, biomass, and abundance correlate with reduced littoral physical habitat complexity (Bettoli et al. 1993; Sass et al. 2006). Anthropogenic regulation of water level regimes is a primary threat to fish species that use the littoral zone for all or part of their lives (Winfield 2004; Miranda et al. 2010; Strayer and Findlay 2010). Annual winter drawdowns can reduce the availability and suitability of spawning habitat, limit the availability of winter habitat refuge from lethal DO concentrations (Cott et al. 2008) and predation, decrease and alter food supplies, and alter the levels of predator-prey and competitive interactions via macrophyte structural and taxonomical composition alteration and density reduction (Wilcox and Meeker 1992).

\section{Feeding trait composition and growth}

Altered and reduced benthic invertebrate assemblages in annual winter drawdown systems negatively affect insectivorous fish species (Haxton and Findlay 2009; Sutela et al. 2011, 2013). Insectivores (e.g., Acipenser fulvescens, Ameiurus nebulosus, Ictalurus punctatus, Lepomis gibbosus) show lower abundances in winter drawdown lakes compared to natural systems (Haxton and Findlay 2009). Furthermore, the density and biomass of insectivorous species tend to decline with increasing drawdown amplitude (Sutela et al. 2011). Sutela et al. (2013) found a positive correlation between abundance of fish insectivores and macroinvertebrate composition (e.g., proportion of sensitive Ephemeroptera, Plecoptera, and Trichoptera taxa) suggesting a potential bottom-up trophic control for insectivores. Reduced littoral habitat structure, such as macrophyte biomass, can shorten food chain length in small lakes (Ziegler et al. 2015, 2017) that can destabilize food web dynamics (McCann et al. 2005). Despite predictions of whole food web structure changes, winter drawdowns show negligible cascading food web impacts (McGowan et al. 2005, Turner et al. 2005), unless amplitudes are extreme for a given lake by severely limiting littoral habitat for consumers and associated productivity (e.g., Black et al. 2003). In extreme annual winter drawdowns (e.g., >10 m), fish generally incorporate more pelagic-derived carbon because of diminished littoral-benthic production (Black et al. 2003).

Habitat generalists, feeding generalists, and species that primarily reside in the pelagic and profundal zones are largely unaffected by annual winter drawdowns (Table 1). For example, Dupont (1994) showed higher catch rates for habitat generalists (e.g., Catostomus macrocheilus) and species that utilize the pelagic zone in a winter drawdown reservoir relative to a natural system. Feeding generalists (e.g., Catostomus commersonii) also maintain high abundances in winter drawdown lakes (McAfee 1980), suggesting resilience to an impoverished littoral macroinvertebrate food supply (Haxton and Findlay 2009). Piscivores with pelagic juvenile stages (e.g., Sander vitreus, S. canadensis) are more abundant in annual winter drawdown lakes, compared to unregulated lakes. Some species (e.g., Notemigonus crysoleucas) show resilience despite heavy predation from Micropterus salmoides (largemouth bass) during a single drawdown event (Wegener and Williams 1975). However, drawdowns constrain available winter habitat, and, where it results in insufficient shelter (e.g., macrophytes, wood, and boulders), can expose fish to increased predation. Increased predation exposure is particularly a problem for small species and YOY (Lantz et al. 1967; Dupont 1994; Paller 1997; Smagula and Connor 2008; Haxton and Findlay 2009). For example, M. salmoides YOY were absent from samples following a relatively deep drawdown $(\sim 1.8 \mathrm{~m})$ in a New Hampshire lake, and it was suggested that this was related to high winter predation levels (Smagula and Connor 2008).

Only a few recent studies on the effects of annual winter drawdowns include fish growth. McDowell (2012) observed slower mean daily growth rates of YOY bluegill in winter drawdown lakes compared to an unregulated lake. Although the mechanisms for slower growth rate are uncertain, benthic invertebrate supply may be limiting (McDowell 2012). Insufficient YOY growth from a reduced benthic invertebrate food supply may explain high winter mortality rates for YOY (Sutela et al. 2013). Predatory piscivores generally benefit from drawdowns because of the increased concentration and exposure to prey relative to pre-drawdown conditions (Henman et al. 1969; Alexander 
1988; Haxton and Findlay 2009). Consequently, growth rates, biomass and relative condition of piscivores increase during- and post-drawdown (Wegener and Williams 1975; Alexander 1988).

Growth rates are highly dependent on local factors (e.g., fish density, food resources, temperature) and several studies report no effect of drawdowns on fish growth. Despite reduced densities of cladocerans and higher numbers of less nutritious rotatorians in a Finland regulated drawdown lake, planktivorous vendace larvae growth rates were comparable to an unregulated system (Sutela and Huusko 1995). Vendace larvae potentially compensate for a low energy diet by increasing consumption when cladoceran densities are low. Shallow systems, although most susceptible to littoral exposure, warm quickly following refill, possibly negating effects of cold winter water temperatures on fish growth (McDowell 2012). Similarly, mild drawdown amplitudes (e.g. $<2 \mathrm{~m}$ ) may not affect YOY growth rates of species that spawn in spring and summer (after refill), including M. salmoides, P. flavascens, and L. macrochirus (McDowell 2012).

\section{Spawning and recruitment}

A winter drawdown-spring refill event can impact littoral spawning species by disturbing spawning and rearing activity, limiting access to spawning habitat, and producing physiological stressful conditions. Impacts are most extreme when regulated water levels are unnaturally low before and during spawning (Ozen and Noble 2002, 2005; Kahl et al. 2008), and during YOY hatching, such that there is limited habitat availability and suitability (Gafny et al. 1992; Wilcox and Meeker 1992), strongly impacting recruitment and year-class strength (Kohler et al. 1993; Neal et al. 2001; Ozen and Noble 2005). Regulated water level fluctuations (e.g., rises and recessions) during spawning can negatively affect juvenile fish densities (Miranda and Lowery 2007), partly due to the loss of physical structural complexity (Neal et al. 2001). For species that spawn in littoral areas in late autumn, winter, and early spring (Table 1), low water levels during the spawning period reduce year class sizes (Kallemeyn 1987a; Sutela et al. 2002). A delay in spring flood peak relative to natural variation limits recruitment for early spring spawning species because of inaccessibility to littoral spawning habitat (Gaboury and Patalas 1984; Kallemeyn 1987a, b; Wilcox and Meeker 1992). For example, Esox niger (chain pickerel), a spring phytophilous spawning species, has experienced population declines in winter drawdown lakes likely because of recruitment failure due to insufficient spawning habitat (Wegener and Williams 1975; McDowell 2012). If water levels are low during the spring, $S$. vitreus (walleye) are unable to find suitable upper littoral habitat for spawning (e.g., stony bottom), with documented negative effects on recruitment (Kallemeyn 1987a). In the same annual winter drawdown system, Larson et al. (2016) found increases in age- 0 abundance of $S$. vitreus and $P$. flavascens in a year after a drawdown amplitude reduction. Although not examined, a winter or spring drought in combination with a regulated drawdown may exacerbate impacts on early spring littoral spawning species (McDowell 2012). Spring refills completed in April at drawdown amplitudes of $<2 \mathrm{~m}$ show negligible effects on spawning timing and frequency for spring and summer spawning species (e.g. Lepomis macrochirus, Perca flavascens, M. salmoides) in multiple Connecticut water bodies (McDowell 2012). Similarly, intra- and inter-annual water level fluctuations did not directly account for annual age- 0 abundances of $S$. viterus and $P$. flavascens potentially because of secondary effects of water level change on aquatic vegetation cover and/or benthic invertebrate food resources (Larson et al. 2016). Winter drawdowns can also affect littoral spawning species if eggs are exposed to desiccation (Gaboury and Patalas 1984; Mills et al. 2002) and low DO concentrations (Sutela et al. 2002). McAfee (1980) recorded significantly lower abundances of Salvelinus fontinalis (brook trout) in winter drawdown lakes potentially due to temporal overlap of water level lowering and their spawning period. Drawdowns and subsequent refills can also benefit recruitment for some fish species. For example, rising water winter levels create newly inundated stones absent of algae, which are necessary for the cyprinid Mirogrex terraesanctae to allow egg adherence and prevent egg mortality (Gafny et al. 1992).

\section{Movement and habitat use}

Winter drawdowns or extremely low winter water levels can induce species-specific sub-lethal responses such as changes in fish movement. The loss of vegetated littoral habitat and/or the increased availability of prey during winter drawdown can cause increased daily movement of largemouth bass (Rogers and Bergersen 1995), which are normally quiescent during the winter (Shuter et al. 2012). In contrast, reduced winter water levels show negligible effects on movement behavior in Esox lucius (northern pike), an active winter species (Rogers and Bergersen 1995). Low winter water levels can also alter life history strategies as seen in Lota lota (burbot). L. lota require suitable daytime shelter to maintain an optimal metabolic rate to ensure somatic growth (Fischer and Öhl 2005). Lowering winter water levels creates high competition for littoral daytime shelters and accelerates their ontogenetic migration from the littoral to the profundal zone (Fischer et al. 2004; Fischer and Öhl 2005). 
For phytophilous species, loss of macrophytes or cooler water temperatures in shallow water during winter drawdown limit access to macrophyte stands in deeper, warmer water, if present (Dupont 1994; Karchesky and Bennet 2004). Dupont (1994) recorded lower abundances of pumpkinseed, largemouth bass, and black crappie in the littoral zone and in deeper areas during a winter drawdown compared to a reference lake. Reduced littoral habitat during the drawdown particularly affected the YOY by increasing exposure to higher flows in this run-of-river reservoir (Dupont 1994). Low spring water levels can also impede movement to littoral refuge habitat. Relative to a reference system, Sutela and Huusko (1995) show low vendace fry densities in nearshore habitats during a winter drawdown, because those areas are prone to sediment entrainment during heavy wind/wave action. Annual winter drawdowns can also decrease the macrophyte structural heterogeneity in the exposure zone (Fig. 2, Wilcox and Meeker 1991), which can alte predator-prey interactions and reduce refuge availability for YOY fish, small fish species, and invertebrates (Wilcox and Meeker 1992).

\section{Winterkill}

Winterkill is a relatively frequent natural disturbance in small boreal and north temperate lakes that structure fish composition and population dynamics (Danylchuck and Tonn 2003, 2006). Winter drawdowns increase the likelihood of fishkills by reducing seasonally low winter DO concentrations (Gaboury and Patalas 1984; Mills et al. 2002; Cott et al. 2008). For example, Mills et al. (2002) recorded extreme abundance decline $(\sim 80 \%)$ of lake whitefish during novel winter drawdowns in a shallow reservoir, associated with low DO concentrations. Stressful conditions (e.g., predator avoidance, low water temperatures) can reduce the tolerance of fish to low DO concentrations (Cott et al. 2008). Species or age classes that seek shallow areas for winter spawning or refuge with relatively low DO replenishment (i.e., a basin with no direct inflows) are most susceptible to fishkills via drawdown (Gaboury and Patalas 1984; Dupont 1994; Mills et al. 2002). Additionally, larger fish (e.g., Esox lucius) are generally more susceptible to low DO levels (see Gaboury and Patalas 1984; Cott et al. 2008).

\section{Research needs}

Despite the numerous studies that investigated the effects of winter lake drawdowns on lake physicochemistry, macrophytes, invertebrates, and fishes, there remain several research gaps. These gaps arise from the limited scope of most drawdown studies, which typically only include a small number of lakes, limited years, and limited response variables. Here, we identify eight key research needs; several of these are aligned with a recent review by Hirsch et al. (2017) on water level fluctuation impacts in hydropower reservoirs. Given that lake ecosystems are increasingly stressed by humans and winter drawdowns are one of the few tools available to address nuisance macrophytes (and other tools such as herbicides and mechanical harvesting have different potential impacts on lakes), increased understanding of impacts of lake drawdowns is critical to compare ecosystem consequences of different management approaches.

\section{Design more studies to expand inferential scope and mechanistic understanding}

Most studies use a before-after study design in a single lake or a reference-experimental approach that typically consist of 2 to 5 lakes (Fig. 4a). Relatively few studies have used a before-after-control-impact (BACI) design, which provides a more suitable control to address interannual variation than before-after designs. Moreover, very few studies include a gradient or reference-experimental approach with $>5$ lakes (Fig. 4a), although these designs have been more common in recent years (Fig. 4b, Supplementary Appendix 1). Studies that include several lakes $(>10)$ are necessary to understand how responses vary among different types of drawdown (i.e., different frequencies, rates, amplitudes, etc.) in different lakes, allowing inference for a broader geographical areas or environmental contexts (e.g., Aroviita and Hämäläinen 2008; White et al. 2011; Mjelde et al. 2012). Further, controlled mesocosm designs can help to isolate causal links between responses and drawdowns by removing confounding factors typically found in observational studies (e.g., Evtimova and Donohue 2014). We advocate, where logistically feasible, for more studies employing gradient and BACI designs at multiple sites, more mesocosm studies, and ultimately more meta-analyses comparing study responses to increase broad understanding of winter drawdown responses.

\section{Develop novel metrics for quantifying drawdown extent based on habitat loss}

Most studies use drawdown amplitude as a measure of the magnitude of drawdown disturbance. While amplitude has been identified as a good predictor of hydrological status and littoral assemblages in regulated Finnish lakes (Keto et al. 2008), lake shape is needed to translate amplitude into water volume and littoral habitat loss. Shallow lakes and littoral zone areas with gentle slopes are more sensitive to water level fluctuations than 
Fig. 4 Winter drawdown studies before 2016 plotted by a total study years against number of lakes per study on a log-scale and with points jittered to remove overlap; and by $\mathbf{b}$ year of publication aggregated in 5 -year bins. Each point represents one study $(\mathrm{n}=72)$ and color-coded by study approach (Before-After $=45$, ReferenceExperimental $=19$, Gradient $=5, \mathrm{BACI}=3$ )
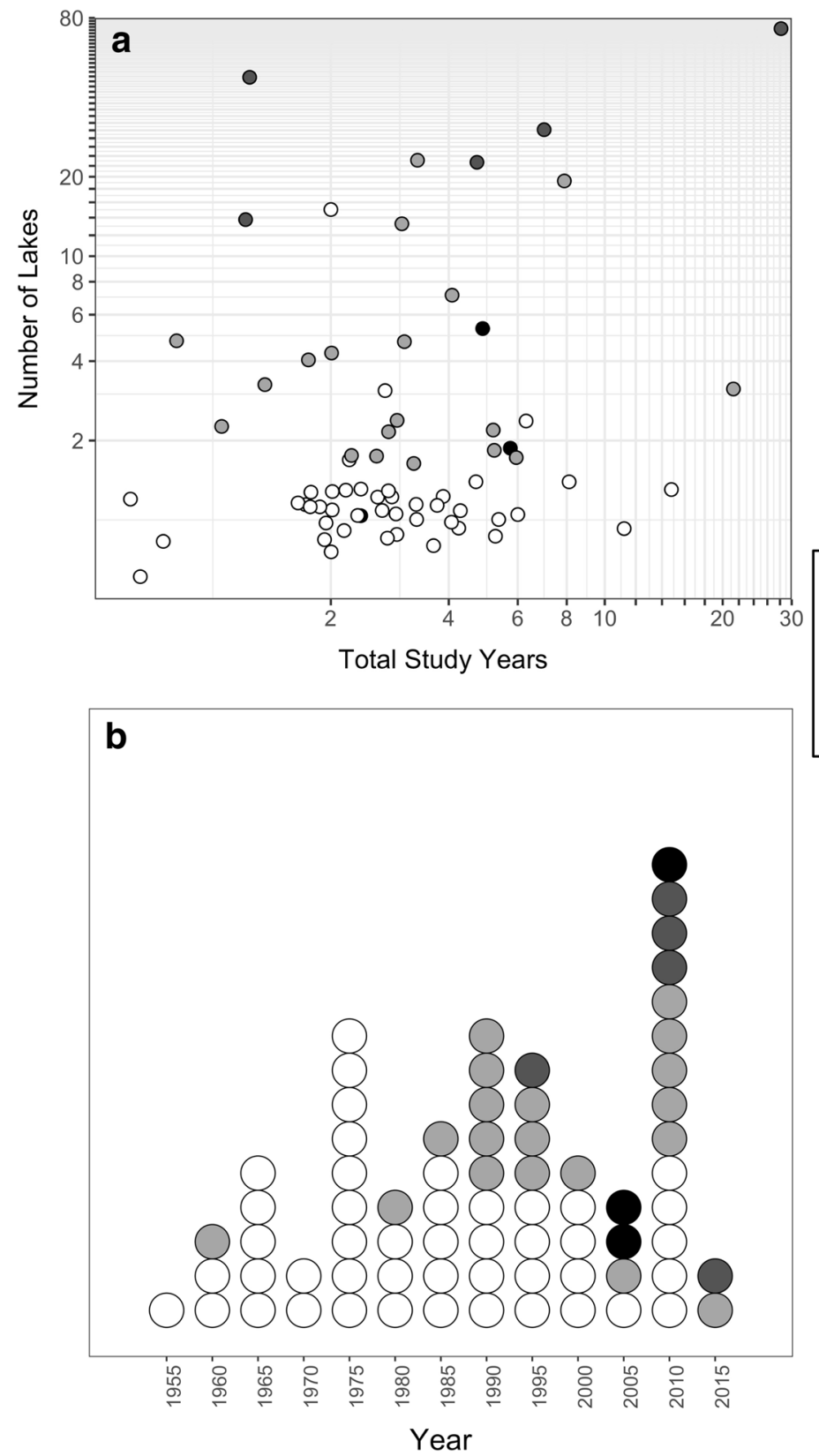

\section{Approach}

O Before-After

O Reference-Experimental

- Gradient

- BACl steeper slope lakes (Coops et al. 2003), with the potential to expose a high proportion of the lake bottom during a relatively moderate low water event (e.g., Beklioglu et al. 2006). The extent or proportion of exposed lake bed relative to the whole lake or littoral zone area can help to predict disturbance in addition to drawdown amplitude. Bathymetric maps and habitat assessments can be used to develop measures of habitat loss associated with drawdowns to better quantify drawdown magnitude and extent, allow more accurate comparisons across lakes, and identify areas particularly susceptible to drawdown.

\section{Quantify multiple characteristics of drawdowns (e.g., duration, timing, frequency, rate)}

Factors other than drawdown amplitude or area of lakebed exposure can predict ecosystem and population-level effects. Water level fluctuation can be described by several additional variables, including duration, timing, frequency, rate of change, and timing of fluctuations (Wantzen et al. 2008). Drawdown duration (i.e., time from drawdown initiation to full refill) in the northeastern US is typically 4-5 months from November through March (Table 1), but shorter or longer drawdown periods may have different ecosystem responses, particularly if the timing avoids 
critical species life history stages (see Larson et al. 2016). Furthermore, drawdown rate can affect responses; if water levels drop fast, less mobile taxa like bivalves (Werner and Rothhaupt 2008) or even small fish (Nagrodski et al. 2012) can become stranded. Differences in frequency of drawdown (e.g. annual, biannual) are rarely investigated; the drawdown history of a lake is critical in assessing current physicochemical and biotic patterns (McDowell 2012) because of potential legacy effects from past water level disturbance (Hall et al. 1999). By incorporating these water level metrics into predictive models, we identify mechanistic links between drawdowns and responses and determine how drawdowns can be managed to minimize impacts.

\section{Measure responses over long time periods (e.g., decades)}

As typical in most ecological studies, studies of winter drawdowns are short in duration with most studies $<5$ years and few studies exceeding 10 years (Fig. 4a). Only a few studies monitor changes in littoral communities across two to three annual drawdowns (Siver et al. 1986; Mills et al. 2002; Turner et al. 2005), and only a few lakes have been studied over long time periods to monitor responses variables after winter drawdown regime change (e.g., Namakan Reservoir: Kraft 1988; McEwen and Butler 2010, Lake Wissota:; Delong and Mundahl 1995; Swanson 2010). Water level fluctuations can be highly variable among lakes and across years (White et al. 2008) due to inter-annual differences in drawdown management and precipitation. Differences in precipitation (and therefore drawdown "success") may mask the ability to detect responses in short-term studies. Moreover, responses to drawdown disturbances may change over time as ecosystems evolve to the new abiotic environment. Long term studies (e.g., $>10$ years) and studies that compare lakes that differ in the number of successive years of drawdown will help to elucidate abiotic and biotic responses to drawdown frequency. Studies incorporating long-term water level records would also provide more water level disturbance context in past years that could explain current littoral biotic patterns (Palomäki 1994) and increase predictive ability of new winter drawdown regimes.

\section{Study lakes with a broad range of natural abiotic factors}

As mentioned previously (\#2) lake morphometry (e.g., area, depth, slope) will affect habitat loss associated with drawdown. Additional abiotic factors may alter the extent of effects of drawdowns, including geology (bed texture, chemistry), climate (e.g., precipitation and ice cover), lake trophic status, and time since reservoir creation (see Hirsch et al. 2017). For example, mesotrophic and eutrophic shallow lakes may be more susceptible to changes in ecosystem states (clear-water to turbid) with drawdowns, whereas effects on deep, stratified lakes may be limited to littoral zones except with deeper drawdowns. Lakes with restricted littoral zones (e.g., deep, steep-sided oligotrophic lakes) could be particularly susceptible to changes in littoral zone community dynamics, including benthic algal production (Vadeboncoeur et al. 2008). Shoreline slope influences the extent of ice-sediment penetration, affecting benthic invertebrate mortality levels (Palomäki and Koskenniemi 1993). Studies across a gradient of environmental conditions will help to parse natural abiotic variation from drawdown effects and better predict drawdown outcomes at a local scale where management typically takes place.

\section{Simultaneously examine multiple sources of anthropogenic stress}

Given that lake drawdowns are frequently conducted to meet human needs, lakes that undergo drawdowns often also have other anthropogenic stressors, such as watershed land use, shoreline development, herbicides, and ongoing climate change. Studies have shown that land use, and particularly development along lake shorelines, can alter littoral habitat and biotic assemblages (Christensen et al. 1996; Francis and Schindler 2009; Brauns et al. 2011; Kovalenko et al. 2014), and thus shoreline development may mask the effects of drawdowns. Furthermore, herbicides and winter drawdowns share the same goal by attempting to control and diminish aquatic vegetation, and are sometimes used simultaneously in the same lake, making it challenging to separate effects of each management practice. Additionally, climate change will likely increase the variability of water level fluctuation extent, duration, and frequency (Wantzen et al. 2008) and reduce ice cover periods (Magnuson et al. 2000). Climate change could also lengthen drawdown periods from winter to summer months, thus increasing lakebed exposure time, with associated consequences to littoral zone communities. Determining the relative importance and potential interaction of winter drawdowns and other threats is critical to predict biotic variation and resilience under changing water level management and climate, and inform lake front owners and managers about how different management approaches interact.

\section{Focus on understudied response variables}

As highlighted in this synthesis, most research on winter drawdowns has been on macrophytes, macroinvertebrates, and fishes (Fig. 3). In contrast, little is known about the influence of winter drawdowns on benthic algal composition; the relative importance of epiphytic, epixylon, and 
epipelon; and benthic algal productivity. Similarly, the effects of winter drawdowns on phytoplankton composition and biomass are covered in few studies (e.g., Vuorio et al. 2015), but also show mixed effects. Further, it is relatively unknown if winter drawdowns promote harmful phytoplankton taxa, as seen only in one study (Nõges and Nõges 1999). Future study on phytoplankton would help determine the role of winter drawdowns in alternative stable state shifts because of the decline of macrophyte assemblages. While there have been some studies on growth of sport fishes and trust species, relatively little is known about fish assemblage responses to drawdown (e.g., Sutela et al. 2011, 2013) and food web interactions (e.g., Black et al. 2003). Semi-aquatic organisms that partially rely on aquatic environments for food resources or refugia (e.g., frogs, turtles, beavers, muskrats, waterbirds) are likely to experience increased risk and stress associated with finding resources (e.g., Smith and Peterson 1991), yet research on potential winter drawdown effects on these taxa are limited.

\section{Scale up studies to include whole-lake ecosystem modeling, functioning, and terrestrial-aquatic linkages}

Winter drawdowns are whole-lake phenomena. As with most lake studies, sampling takes place in parts of the lake, and the responses are assumed to be representative of the entire lake. This assumption may be flawed especially in lakes with highly diverse habitats. Furthermore, whole-lake assessments of ecosystem functioning, such as energy fluxes and nutrient dynamics do not exist in winter drawdown lakes, and these may constitute important responses to lake drawdowns. There is limited study on the release of limiting nutrients upon spring inundation and the corresponding effect on primary production and consumers. Given winter drawdowns are used in part to reduce macrophytes, understanding the role of littoral refuge reduction for consumers in winter drawdown lakes will help to predict stability of predator-prey dynamics and whole lake ecosystem functioning. Additionally, the lake-wide extent of organic matter redistribution to deeper depths and the concurrent changes of sediment stoichiometry has only been shown in few studies (e.g., Furey et al. 2004). If shorelines are not heavily developed, potential declines in benthic autochthonous primary production and increases in allochthonous organic matter in the drawdown exposure zone (Furey et al. 2004) could increase energetic connectivity between riparianlake environments. More studies are needed to determine the relative influence and interaction of human stressors on the strength of riparian-lake energetic linkages in winter drawdown lakes.

\section{Conclusion}

As described in this review, many studies have documented the numerous and varied effects of winter water level drawdowns on littoral zone communities. Given that each lake has unique environmental characteristics and lakes are typically managed individually, research that encompasses a gradient of lake conditions and identifies factors influencing varied responses are critical to apply research to inform lake management. Further, incorporating depth gradients in monitoring plans will increase accuracy and prediction of winter drawdown responses at shoreline and lake-level scales (Evtimova and Donohue 2016). Also, incorporating anticipated climate change effects on water level fluctuations will help lake managers in drawdown systems to mitigate potential extreme fluctuations within lake-specific thresholds, particularly in lakes with current moderate drawdown amplitudes (Abrahams 2008).

Increasing human populations are demanding more services (e.g., energy, recreation, food) from lakes, putting added stress on lake ecosystems. Most lake management plans aim to simultaneously meet both human and ecosystem needs. Since annual winter drawdowns are conducted to achieve various human purposes (e.g., hydroelectric power, aquatic vegetation and fish management), understanding the nuances of purpose-specific drawdown regimes and its ecological impacts can provide a more holistic management decision-making process. Research designs with direct application to management (e.g., adaptive management) will further our understanding of lake ecological responses and facilitate effective restoration among a growing and interacting array of anthropogenic pressures.

Acknowledgements This paper was funded by the Massachusetts Division of Fisheries and Wildlife. Feedback from Paula Furey greatly improved this manuscript. Thanks to Amy Smagula and Gabe Cries for their help locating relevant studies. Symbols on the diagrams are courtesy of the Integration and Application Network (https://www. ian.umces.edu/symbols). Any use of trade, firm, or product names is for descriptive purposes only and does not imply endorsement by the U.S. Government.

Open Access This article is distributed under the terms of the Creative Commons Attribution 4.0 International License (http:// creativecommons.org/licenses/by/4.0/), which permits unrestricted use, distribution, and reproduction in any medium, provided you give appropriate credit to the original author(s) and the source, provide a link to the Creative Commons license, and indicate if changes were made. 


\section{References}

Abrahams C (2006) Sustainable shorelines: the management and revegetation of drawdown zones. J Pract Ecol Conserv 6:37-51

Abrahams C (2008) Climate change and lakeshore conservation: a model and review of management techniques. Hydrobiologia 613:33-43

Alasaarela E, Hellsten S, Tikkanen P (1989) Ecological aspects of lake regulation in northern Finland. River Basin Manag 5:247-255

Alexander CM (1988) Impact assessment of extreme drawdown on the Watauga Reservoir fishery. In: Proceedings of the annual conference southeastern association of fish and wildlife agencies 40:15-26

Aroviita J, Hämäläinen H (2008) The impact of water-level regulation on littoral macroinvertebrate assemblages in boreal lakes. Hydrobiologia 613:45-56

Arthaud F, Vallod D, Robin J, Bornette G (2012) Eutrophication and drought disturbance shape functional diversity and lifehistory traits of aquatic plants in shallow lakes. Aquat Sci $74: 471-481$

Bakker ES, Hilt S (2016) Impact of water-level flcutuations on cyanobacterial blooms: options for management. Aquat Ecol 50:485-498

Baldwin DS (1996) Effects of exposure to air and subsequent drying on the phosphate sorption characteristics of sediments from a eutrophic reservoir. Limnol Oceanogr 41:1725-1732

Baldwin DS, Mitchell AM (2000) The effects of drying and reflooding on the sediment and soil nutrient dynamics of lowland river-floodplain systems: a synthesis. Regul Rivers Res Manag 16:457-467

Barko JW, Smart RM (1986) Sediment-related mechanisms of growth limitation in submersed macrophytes. Ecology 67(5):1328-1340

Baumgärtner D, Mörtl M, Rothhaupt KO (2008) Effects of waterdepth and water-level fluctuations on the macroinvertebrate community structure in the littoral zone of Lake Constance. Hydrobiologia 613:97-107

Beard TD (1973) Overwinter drawdown: impact on the aquatic vegetation in Murphy Flowage, Wisconsin. Wisconsin Department of Natural Resources, Madison

Beauchamp DA, Byron ER, Wurtsbaugh WA (1994) Summer habitat use by littoral-zone fishes in Lake Tahoe and the effects of shoreline structures. North Am J Fish Manag 14:385-394

Beklioglu M, Altinayar G, Tan CO (2006) Water level control over submerged macrophyte development in five shallow lakes of Mediterranean Turkey. Archiv für Hydrobiol 166:535-556

Benson NG (1973) Evaluating the effects of discharge rates, water levels, and peaking on fish populations in Missouri River main stem impoundments. Geophys Monogr Ser 17:683-689

Benson NG, Hudson PL (1975) Effects of a reduced drawdown on benthos abundance in Lake Francis Case. Trans Am Fish Soc 104:526-528

Bettoli PW, Maceina MJ, Noble RL, Betsill RK (1993) Response of a reservoir fish community to aquatic vegetation removal. North Am J Fish Manag 13:110-124

Black AR, Barlow GW, Scholz AT (2003) Carbon and nitrogen stable isotope assessment of the Lake Roosevelt aquatic food web. Northwest Sci 77:1-11

Blais JM, Kalff J (1995) The influence of lake morphometry on sediment focusing. Limnol Oceanogr 40:582-588

Blindow I (1992) Long- and short-term dynamics of submerged macrophytes in two shallow eutrophic lakes. Freshw Biol 28:15-27

Bornette G, Puijalon S (2011) Response of aquatic plants to abiotic factors: a review. Aquat Sci 73:1-14
Boschilia SM, De Oliveira EF, Schwarzbold A (2012) The immediate and long-term effects of water drawdown on macrophyte assemblages in a large subtropical reservoir. Freshw Biol 57:2641-2651

Brauns M, Garcia XF, Pusch MT (2008) Potential effects of waterlevel fluctuations on littoral invertebrates in lowland lakes. Hydrobiologia 613:5-12

Brauns M, Gücker B, Wagner C, Garcia X-F, Walz N, Pusch MT (2011) Human lakeshore development alters the structure and trophic basis of littoral food webs. J Appl Ecol 48:916-925

Cantonati M, Scola S, Angeli N, Guella G, Frassanito R (2009) Environmental controls of epilithic diatom depth-distribution in an oligotrophic lake characterized by marked water-level fluctuations. Eur J Phycol 44(1):15-29

Cantonati M, Lowe RL (2014) Lake benthic algae: toward an understanding of their ecology. Freshw Sci 33:475-486

Cantonati M, Guella G, Komárek J, Spitale D (2014) Depth distribution of epilithic cyanobacteria and pigments in a mountain lake characterized by marked water-level fluctuations. Freshw Sci 33:537-547

Casanova MT, Brock MA (2000) How do depth, duration and frequency of flooding influence the establishment of wetland plant communities? Plant Ecol 147:237-250

Chick JH, McIvor CC (1994) Patterns in the abundance and composition of fished among beds of different macrophytes: viewing a littoral zone as a landscape. Can J Fish Aquat Sci 51:2873-2882

Christensen DL, Herwig BR, Schindler DE, Carpenter SR (1996) Impacts of lakeshore residential development on coarse woody debris in north temperate lakes. Ecol Appl 6:1143-1149

Combroux ICS, Bornette G (2004) Propagule banks and regenerative strategies of aquatic plants. J Veg Sci 15:13-20

Cooke GD (1980) Lake level drawdown as a macrophyte control technique. Water Resour Bull 16:317-322

Cooke GD, Welch EB, Peterson SA, Nichols SA (2005) Restoration and management of lakes and reservoirs, 3rd edn. CRC Press Boca Raton, Florida

Coops H, Hosper SH (2002) Water-level management as a tool for the restoration of shallow lakes in the Netherlands. Lake Reserv Manag 18:293-298

Coops H, Beklioglu M, Crisman TL (2003) The role of water-level fluctuations in shallow lake ecosystems-workshop conclusions. Hydriobiologia 506-509:23-27

Corstanje R, Reddy KR (2004) Response of biogeochemical indicators to a drawdown and subsequent reflood. J Environ Qual 33:2357-2366

Cott PA, Sibley PK, Gordon AM et al (2008) Effects of water withdrawal from ice-covered lakes on oxygen, temperature, and fish. J Am Water Resour Assoc 44:328-342

Cyr H (1998) Effects of wave disturbance and substrate slope on sediment characteristics in the littoral zone of small lakes. Can J Fish Aquat Sci 55:967-976

Danylchuk AJ, Tonn WM (2003) Natural disturbances and fish: local and regional influences on winterkill of fathead minnows in boreal lakes. Trans Am Fish Soc 132:289-298

Danylchuk AJ, Tonn WM (2006) Natural disturbance and life history: consequences of winterkill on fathead minnow in boreal lakes. $\mathbf{J}$ Fish Biol 68:681-694

de Vicente I, Andersen FØ, Hansen HCB et al (2010) Water level fluctuations may decrease phosphate adsorption capacity of the sediment in oligotrophic high mountain lakes. Hydrobiologia 651:253-264

Delong MD, Mundahl ND (1995) Effects of late-winter drawdown on benthic invertebrate community structure in the littoral zone of Lake Wissota, Wisconsin. Report to the Wisconsin Department of Natural Resources, Eau Claire, Wisconsin, USA 
Devlin SP, Vander Zanden MJ, Vadeboncoeur Y (2013) Depthspecific variation in carbon isotopes demonstrates resource partitioning among the littoral zoobenthos. Freshw Biol 58:2389-2400

Diehl S (1988) Foraging efficiency of three freshwater fishes of structural complexity and light. Oikos 53:207-214

Dupont JM (1994) Fish habitat associations and effects of drawdown on fishes in Pend Oreille River. Thesis, University of Idaho, Moscow, Idaho, USA

Effler SW, Matthews DA (2004) Sediment resuspension and drawdown in a water supply reservoir. J Am Water Resour Assoc 40:251-264

Erixon G (1981) Aquatic macrophytes and their environment in the Vindelälven river, northern Sweden. Wahlenbergia 7:61-71

Evtimova VV, Donohue I (2014) Quantifying ecological responses to amplified water level fluctuations in standing waters: an experimental approach. J Appl Ecol 51:1282-1291

Evtimova VV, Donohue I (2016) Water-level fluctuations regulate the structure and function of natural lakes. Freshw Biol 61:251-264

Fillion DB (1967) The abundance and distribution of benthic fauna of three mountain reservoirs on the Kananaskis River in Alberta. J Appl Ecol 1-11

Fischer P, Öhl U (2005) Effects of water-level fluctuations on the littoral benthic fish community in lakes: a mesocosm experiment. Behav Ecol 16:741-746

Fischer P, Öhl U, Wacker N (2004) Effects of seasonal water level fluctuations on the benthic fish community in lakes-a case study of juvenile burbot Lota lota L. Ecohydrol Hydrobiol 4:481-486

Fiske S (1989) The effects of a winter lake level drawdown on the benthic macroinvertebrate communities from several population assemblages/habitat areas around Lake Bomoseen, Vermont. Vermont Department of Environmental Conservation Special Studies and Surveillance Unit, Montpelier, Vermont, USA

Fox J, Brezonick PL, Keirn MA (1977) Lake drawdown as a method for improving water quality. U.S. Environmental Protection Agency, Corvallis Environmental Research Laboratory, Corvallis

Francis TB, Schindler DE (2009) Shoreline urbanization reduces terrestrial insect subsidies to fishes in North American lakes. Oikos 118:1872-1882

Free G, Solimini AG, Rossaro B et al (2009) Modelling lake macroinvertebrate species in the shallow sublittoral: relative roles of habitat, lake morphology, aquatic chemistry and sediment composition. Hydrobiologia 633:123-136

Furey PC, Nordin RN, Mazumder A (2004) Water level drawdown affects physical and biogeochemical properties of littoral sediments of a reservoir and a natural lake. Lake Reserv Management 20:280-295

Furey PC, Nordin RN, Mazumder A (2006) Littoral benthic macroinvertebrates under contrasting drawdown in a reservoir and a natural lake. J N Am Benthol Soc 25:19-31

Gaboury MN, Patalas JW (1984) Influence of water level drawdown on the fish populations of Cross Lake, Manitoba. Can J Fish Aquat Sci 41:118-125

Gafny S, Gasith A, Goren M (1992) Effect of water level fluctuation on shore spawning of Mirogrex terrasanctae (Steinitz), (Cyprinidae) in Lake Kinneret, Israel. J Fish Biol 41:863-871

Gasith A, Gafny S (1990) Effects of water level fluctuation on the structure and function of the littoral zone. Pages 156-171 in M. M. Tilzer and C. Serruya, editors. Large lakes: ecological structure and function. Springer, Berlin

Gathman JP, Burton TM (2011) A great lakes coastal wetland invertebrate community gradient: relative influence of flooding regime and vegetation zonation. Wetlands 31:329-341
Gertzen E, Doka S, Minns C et al (2012) Effects of water levels and water level regulation on the supply of suitable spawning habitat for eight fish guilds in the Bay of Quinte, Lake Ontario. Aquat Ecosyst Heal Manag 15:397-409

Gottgens JF (1994) Redistribution of organic sediments in a shallow lake following a short-term drawdown. Archiv für Hydrobiol 130:179-194

Grimås U (1961) The bottom fauna of natural and impounded lakes in northern Sweden (Ankarvattnet and Blåsjön). Inst Freshw Res Drottningholm Rep 42:183-237

Grimås U (1965) The short-term effect of artificial water-level fluctuations upon the littoral fauna of Lake Kultsjön, northern Sweden. Inst Freshw Res Drottningholm Rep 46:5-21

Grime J (1977) Evidence for the existence of three primary strategies in plants and its relevance to ecological and evolutionary theory. Am Nat 111:1169-1194

Groen CL, Schroeder TA (1978) Effects of water level management on walleye and other coolwater fishes in Kansas reservoirs. Am Fish Soc Spec Publ 11:278-283

Håkanson L (1977) The influence of wind, fetch, and water depth on the distribution of sediments in Lake Vänern, Sweden. Can J Earth Sci 14:397-412

Hall RI, Leavitt PR, Dixit AS, Quinian R, Smol JP (1999) Limnological succession in reservoirs: a paleolimnological comparison of two methods of reservoir formation. Can J Fish Aquat Sci 56:1109-1121

Havens KE, Sharfstein B, Brady MA, East TL, Harwell MC, Maki RP, Rodusky AJ (2004) Recovery of submerged plants from high water stress in a large subtropical lake in Florida, USA Aquat Bot 78:67-82

Haxton TJ, Findlay CS (2008) Meta-analysis of the impacts of water management on aquatic communities. Can J Fish Aquat Sci 65(447):437-447

Haxton TJ, Findlay CS (2009) Variation in large-bodied fish-community structure and abundance in relation to water-management regime in a large regulated river. J Fish Biol 74:2216-2238

Heino J (2008) Patterns of functional biodiversity and function-environment relationships in lake littoral macroinvertebrates. Limnol Oceanogr 53:1446-1455

Hellsten SK (1997) Environmental factors related to water level regulation - a comparative study in northern Finland. Boreal Environ Res 2:345-367

Hellsten SK (2000) Environmental factors and aquatic macrophytes in the littoral zone of regulated lakes: causes, consequences and possibilities to alleviate harmful effects. Thesis, University of Oulu, Oulu, Finland

Hellsten S (2002) Aquatic macrophytes as indicators of water-level regulation in Nothern Finland. Verh Internat Verein Limnol 28:601-606

Hellsten S, Riihimäki J (1996) Effects of lake water level regulation on the dynamics of littoral vegetation in northern Finland. Hydrobiologia 340:85-92

Hellsten S, Marttunen M, Palomäki R, Riihimäki J, Alasaarela E (1996) Towards an ecologically based regulation practice in Finnish hydroelectric lakes. Regul Rivers Res Manag 12:535-545

Henman ML, Campbell RS, Redmond LC (1969) Manipulation of fish populations through reservoir drawdowns. Trans Am Fish Soc 98:293-304

Hestand RS, Carter CC (1974) The effects of a winter drawdown on aquatic vegetation in a shallow water reservoir. Hyacinth Control J 12:9-12

Hill NM, Keddy PA, Wisheu IC (1998) A hydrological model for predicting the effects of dams on the shoreline vegetation of lakes and reservoirs. Environ Manage 22:723-736 
Hirsch PE, Eloranta AP, Amundsen P-A, Brabrand Å, Charmasson J, Helland IP, Power M, Sánchez-Hernández J, Sandlund OT, Sauterleute JF, Skoglund S, Ugedal O, Yang H (2017) Effects of water level regulation in alpine hydropower reservoirs: an ecosystem perspective with a special empahsis on fish. Hydrobiologia 794:287-301

Hofmann H, Lorke A, Peeters F (2008) Temporal scales of water-level fluctuations in lakes and their ecological implications. Hydrobiologia 613:85-96

Howard RJ, Wells CJ (2009) Plant community establishment following drawdown of a reservoir in southern Arkansas, USA. Wetlands Ecol Manage 17:565-583

Hulsey AH (1957) Effects of a fall and winter drawdown on a flood control lake. In: Proceedings of the annual conference southeastern association of game and fish commissioners 10:285-289

Hugh Barwick D (2004) Species richness and centrarchid abundance in littoral habitats of three southern U.S. reservoirs. N Am J Fish Manage 24(1):76-81

James WF, Barko JW, Eakin HL, Helsel DL (2001) Changes in sediment characteristics following drawdown of Bid Muskego Lake, Wisconsin. Archiv für Hydrobiol 151:459-474

Jensen HS, Andersen FO (1992) Importance of temperature, nitrate, and $\mathrm{pH}$ for phosphate release from aerobic sediments of four shallow, eutrophic lakes. Limnol Oceanogr 37:577-589

Kahl U, Hülsmann S, Radke RJ, Benndorf J (2008) The impact of water level fluctuations on the year class strength of roach: implications for fish stock management. Limnologica 38:258-268

Kallemeyn LW (1987a) Correlations of regulated lake levels and climatic factors with abundance of young-of-the-year walleye and yellow perch in four lakes in Voyageurs National Park. North Am J Fish Manag 7:513-521

Kalleymeyn LW (1987b) Effects of regulated lake levels on nothern pike spawning habitat and reproductive success in Namakan Reservoir, Voyageurs National Park. National Park Service, Midwest Region, Research/Resources Management Report MWR-8

Karchesky CM, Bennett DH (2004) Winter habitat use by adult largemouth bass in the Pend Oreille River. North Am J Fish Manag 24:577-585

Kaster JL, Jacobi GZ (1978) Benthic macroinvertebrates of a fluctuating reservoir. Freshw Biol 8:283-290

Keast A (1978) Trophic and spatial interrelationships in the fish species of an Ontario temperate lake. Environ Biol Fishes 3:7-31

Keddy PA, Reznicek AA (1986) Great Lakes vegetation dynamics: the role of fluctuating water levels and buried seeds. J Great Lakes Res 12:25-36

Keto A, Tarvainen A, Hellsten S (2006) The effect of water level regulation on species richness and abundance of aquatic macrophytes in Finnish lakes. Verh des Int Ver Limnol 29:2103-2108

Keto A, Tarvainen A, Marttunen M, Hellsten S (2008) Use of the water-level fluctuation analysis tool (Regcel) in hydrological status assessment of Finnish lakes. Hydrobiologia 613:133-142

Klotz RL, Linn SA (2001) Influence of factors associated with water level drawdown on phosphorous release from sediments. J Lake Reserv Manag 37:48-54

Koch EW (2001) Beyond light: physical, geological, and geochemical parameters as possible submersed aquatic vegetation habitat requirements. Estuaries 24:1-17

Kohler CC, Sheehan RJ, Sweatman JJ (1993) Largemouth bass hatching success an first-winter survival in two Illinois reservoirs. $\mathrm{N}$ Am J Fish Manag 13:125-133

Koskenniemi E (1994) Colonization, succession and environmental conditions of the macrozoobenthos in a regulated, polyhumic reservoir, western Finland. Int Revue der gesamten Hydrobiol $4: 521-555$
Kovalenko KE, Brady VJ, Ciborowski JH, Ilyushkin S, Johnson LB (2014) Functional changes in littoral macroinvertebrate communities in response to watershed-level anthropogenic stress. PLOS One 9:e101499

Kraft KJ (1988) Effect of increased winter drawdown on benthic macroinvertebrates in Namakan Reservoir, Voyageurs National Park. National Park Service, Midwest Region, Research/ Resources Management Report MWR-12

Lantz KE, Davis JT, Hughes JS, Schafer Jr. HE (1967) Water level fluctuation-its effects on vegetation control and fish population management. In: Proceedings of the annual conference southeastern association of game and fish commissioners 18:483-494

Larson JH, Staples DF, Maki RP, Vallazza JM, Knights BC, Peterson KE (2016) Do water level fluctuations influence production of walleye and yellow perch young-of-year in large nothern lakes? N Am J Fish Manag 36:1425-1436

Leira M, Cantonati M (2008) Effects of water-level fluctuations on lakes: an annotated bibliography. Hydrobiologia 613:171-184

Lewin W-F, Okun N, Mehner T (2004) Determinants of the distribution of juvenile fish in the littoral area of a shallow lake. Freshw Biol 49:410-424

Lorang MS, Komar PD, Stanford JA, Stanfordt JA (1993) Lake level regulation and shoreline erosion on Flathead Lake, Montana: a response to the redistribution of annual wave energy. J Coast Res 9:494-508

Luettich RA Jr, Harleman DRF, Somlyody L (1990) Dynamic behavior of susepnded sediment concentrations in a shallow lake perturbed by episodic wind events. Limnol Oceanogr 35:1050-1067

Luken JO, Bezold TN (2000) Plant communities associated with different shoreline elements at Cave Run Lake, Kentucky. Wetlands 20:479-486

Magnuson JJ, Robertson DM, Benson BJ, Wynne RH, Livingstone DM, Arai T, Assel RA, Barry RG, Card V, Kuusisto E, Granin NG, Prowse TD, Stewart KM, Vuglinski VS (2000) Historical trends in lake and river ice cover in the northern hemisphere. Science 289:1743-1746

Mattson MD, Godfrey PJ, Barletta RA, Aiello A (2004) Eutrophication and plant management in Massachusetts. Water Resources Research Center. University of Massachusetts, Amherst

McAfee ME (1980) Effects of water drawdown on the fauna in small cold water reservoirs. Water Resour Bull 16:690-696

McCann KS, Rasmussen JB, Umbanhowar J (2005) The dynamics of spatially coupled food webs. Ecol Lett 8:513-523

McDowell CP (2012) Winter drawdown effects on swim-up date and growth rate of age-0 fishes in Connecticut. Thesis, University of Connecticut, Storrs, Connecticut, USA

McEwen DC, Butler MG (2010) The effects of water-level manipulation on the benthic invertebrates of a managed reservoir. Freshw Biol 55:1086-1101

Mcgowan S, Leavitt PR, Hall RI (2005) A whole-lake experiment to determine the effects of winter droughts on shallow lakes. Ecosystems 8:694-708

Mills KH, Chalanchuk SM, Allan DJ, Bodaly RA (2002) Abundance, survival, condition, and recruitment of lake whitefish (Coregonus clupeaformis) in a lake subjected to winter drawdown. Adv Limnol 57:209-219

Miranda LE, Lowery DR (2007) Juvenile densities relative to water regime in mainstem reservoirs of the Tennessee River, USA. Lakes Reserv Res Manag 12:87-96

Miranda LE, Driscoll MP, Allen MS (2000) Transient physicochemical microhabitats facilitate fish survival in inhospitable aquatic plant stands. Freshw Biol 44:617-628

Miranda LE, Spickard M, Dunn T, Webb KM, Aycock JN, Hunt K (2010) Fish habitat degradation in US Reservoirs. Fisheries $35: 175-184$ 
Mitchell A, Baldwin DS (1998) Effects of desiccation/oxidation on the potential for bacterially mediated $\mathrm{P}$ release from sediments. Limnol Oceanogr 43:481-487

Mjelde M, Hellsten S, Ecke F (2012) A water level drawdown index for aquatic macrophytes in Nordic lakes. Hydrobiologia 704:141-151

Nagrodski A, Raby GD, Hasler CT, Taylor MK, Cooke SJ (2012) Fish stranding in freshwater systems: sources, consequences, and mitigation. J Environ Manage 103:133-141

Neal JW, Bacheler NM, Noble RL, Lilyestrom CG (2001) Effects of reservoir drawdown on available habitat: implications for a tropical Largemouth Bass population. In: Proceedings of the annual conference of southeastern association of fish and wildlife agencies 55:156-164

Nichols SA (1975) The use of overwinter drawdown for aquatic vegetation management. Water Resour Bull 11:1137-1148

Nõges T, Nõges P (1999) The effect of extreme water level decrease oh hydrochemistry and phytoplankton in a shallow eutrophic lake. Hydrobiologia 408/409:277-283

Olila OG, Reddy KR, Sites DL (1997) Influence of draining on soil phosphorous forms and distribution in a constructed wetland. Ecol Eng 9:157-169

Olson ER, Ventura SJ, Zedler JB (2012) Merging geospatial and field data to predict the distribution and abundance of an exotic macrophyte in a large Wisconsin reservoir. Aquat Bot 96:31-41

Ozen O, Noble RL (2002) Relationship between water level fluctuations and largemouth bass spawning in a Puerto Rico reservoir. Am Fish Soc Symp 31:213-220

Ozen O, Noble RL (2005) Relationship between largemouth bass recruitment and water level dynamics in a Puerto Rico reservoir. Lake Res Manage 21(1):89-95

Palomäki R (1994) Response by macrozoobenthos biomass to water level regulation in some Finnish lake littoral zones. Hydrobiologia 286:17-26

Paller MH (1997) Recovery of a reservoir fish community from drawdown related impacts. N Am J Fish Manage 17(3):726-733

Palomäki R, Hellsten S (1996) Littoral macrozoobenthos biomass in a continuous habitat series. Hydrobiologia 339:85-92

Palomäki R, Koskenniemi E (1993) Effects of bottom freezing on macrozoobenthos in the regulated Lake Pyhäjärvi. Archiv für Hydrobiol 128:73-90

Paterson CG, Fernando CH (1969) The effect of winter drainage on reservoir benthic fauna. Can J Zool 47:589-595

Peters JA, Lodge DM (2009) Littoral Zone. In: Likens GE (ed) Encyclopedia of inland waters, vol 1. Elsevier, Oxford, pp 79-87

Peverly JH, Kopka RJ (1991) Changes in AL, Mn and Fe from sediments and aquatic plants after lake drawdown. Water Air Soil Pollut 57-58:399-410

Ploskey GR (1983) A review of the effects of water level changes on reservoir fisheries and recommendations for improved management. Technical Report E-83-3, prepared by the Fish and Wildlife Service, US Department of the Interior, for the US Army Engineer Waterways Experiment Station, CE, Vicksburg, MI

Pratt TC, Smokorowski KE (2003) Fish habitat management implications of the summer habitat use by littoral fishes in a north temperate, mesotrophic lake. Can J Fish Aquat Sci 60:286-300

Pugh PJA, Davenport J (1997) Colonisation vs. disturbance: the effects of sustained ice-scouring on intertidal communities. J Exp Mar Biol Ecol 210:1-21

Qiu S, McComb AJ (1994) Effects of oxygen concentration on phosphorous release from reflooded air-dried wetland sediments. Aust J Mar Freshwat Res 45:1319-1328

Qiu S, McComb AJ (1995) Planktonic and microbial contributions to phosphorous release from fresh and air-dried sediments. Mar Freshw Res 46:1039-1045
Qiu S, McComb AJ (1996) Drying-induced stimulation of ammonium release and nitrification in reflooded lake sediment. Mar Freshw Res 47:531-536

Randall RG, Brousseau CM, Hoyle JA (2012) Effect of aquatic macrophyte cover and fetch on spatial variability in the biomass and growth of littoral fishes in bays of Prince Edward County, Lake Ontario. Aquat Ecosyst Health Manag 15:385-396

Renman G (1989) Distribution of littoral macrophytes in a north Swedish riverside lagoon in relation to bottom freezing. Aquat Bot 33:243-256

Renman G (1993) Frost formation in the ecotonal zone and its role for release of nutrients. Hydrobiologia 251(1-3):65-72

Riis T, Hawes I (2002) Relationships between water level fluctuations and vegetation diversity in shallow water of New Zealand lakes. Aquat Bot 74:133-148

Riis T, Hawes I (2003) Effect of wave exposure on vegetation abundance, richness and depth distribution of shallow water plants in a New Zealand lake. Freshw Biol 48:75-87

Rogers KB, Bergersen EP (1995) Effects of a fall drawdown on movement of adult northern pike and largemouth bass. N Am J Fish Manag 15:596-600

Rørslett B (1984) Environmental factors and aquatic macrophyte response in regulated lakes - a statistical approach. Aquat Bot 19:199-220

Rørslett B (1988) An integrated approach to hydropower impact assessment. I. Environmental features of some Norwegian hydro-electric lakes. Hydrobiologia 164:39-66

Rørslett B (1989) An integrated approach to hydropower impact assessment. II. Submerged macrophytes in some Norwegian hydro-electric lakes. Hydrobiologia 175:65-82

Rowan DJ, Kalff J, Rasmussen JB (1992) Estimating the mud deposition boundary depth in lakes from wave theory. Can J Fish Aquat Sci 49:2490-2497

Samad F, Stanley JB (1986) Loss of freshwater shellfish after water drawdown in Lake Sebasticook, Maine. J Freshw Ecol 3:519-523

Sass GG, Kitchell JF, Carpenter SR, Hrabik TR, Marburg AE, Turner MG (2006) Fish Community and food web responses to a whole-lake removal of coarse woody habitat. Fisheries 31:321-330

Savino JF, Stein RA (1989) Behavioural interactions between fish predators and their prey: effects of plant density. Anim Behav 37:311-321

Scheifhacken N, Fiek C, Rothhaupt K (2007) Complex spatial and temporal patterns of littoral benthic communities interacting with water level fluctuations and wind exposure in the littoral zone of a large lake. Fundam Appl Limnol 169:115-129

Sephton TW, Paterson CG (1986) Production of the chironomid Procladius bellus in an annual drawdown reservoir. Freshw Biol 16:721-733

Shantz M, Dowsett E, Canham E et al (2004) The effect of drawdown on suspended solids and phosphorus export from Columbia Lake, Waterloo, Canada. Hydrol Process 18:865-878

Shuter BJ, Finstad AG, Helland IP, Zweimüller I, Hölker F (2012) The role of winter phenology in shaping the ecology of freshwater fish and their sensitivities to climate change. Aquat Sci 74:637-657

Siver PA, Coleman AM, Benson GA, Simpson JT (1986) The effects of winter drawdown on macrophytes in Candlewood Lake, Connecticut. Lake Reserv Manag 2:69-73

Smagula AP, Connor J (2008) Ashuelot Pond, Washington, New Hampshire drawdown study. New Hampshire Department of Environmental Services, Water Division, Watershed Management Bureau, Concord 
Smith DW, Peterson RO (1991) Behavior of beaver in lakes with varying water levels in Northern Minnesota. Environ Manag 15:395-401

Song K-Y, Zoh K-D, Kang H (2007) Release of phosphate in a wetland by changes in hydrological regime. Sci Total Environ 380:13-18

Steinman A, Chu X, Ogdahl M (2009) Spatial and temporal variability of internal and external phosphorus loads in Mona Lake, Michigan. Aquatic Ecol 43(1):1-18

Steinman AD, Ogdahl ME, Weinert M, Thompson K, Cooper MJ, Uzarski DG (2012) Water level fluctuation and sediment-water nutrient exchange in Great Lakes coastal wetlands. J Great Lakes Res 38:766-775

Stendera S, Adrian R, Bonada N, Cañedo-Argüelles M, Hugueny B, Januschke K, Pletterbauer F, Hering D (2012) Drivers and stressors of freshwater biodiversity patterns across different ecosystems and scales: a review. Hydrobiologia 696:1-28

Strayer DL, Findlay SEG (2010) Ecology of freshwater shore zones. Aquat Sci 72:127-163

Sutela T, Huusko A (1995) Impacts of water level regulation on the early life of vendace (Coregonus albula L.). Int Symp Biol Manag Coregonid Fishes 46:465-472

Sutela T, Mutenia A, Salonen E (2002) Relationship between annual variation in reservoir conditions and year-class strength of peled (Coregonus peled) and whitefish (C. lavaretus). Hydrobiologia 485:213-221

Sutela T, Vehanen T, Rask M (2011) Assessment of the ecological status of regulated lakes: stressor-specific metrics from littoral fish assemblages. Hydrobiologia 675:55-64

Sutela T, Aroviita J, Keto A (2013) Assessing ecological status of regulated lakes with littoral macrophyte, macroinvertebrate and fish assemblages. Ecol Indic 24:185-192

Swanson J (2010) Postdrawdown composition of the benthic invertebrate community of Lake Wissota, Wisconsin. Beaver Creek Reserve-Citizen Science Center, Fall Creek

Tarver DP (1980) Water fluctuation and the aquatic flora of Lake Miccosukee. J Aquat Plant Manag 18:19-23

Tazik PP, Kodrich WR, Moore JR (1982) Effect of overwinter drawdown on bushy pondweed. J Aquat Plant Manag 20:19-21

Thomaz SM, Pagioro TA, Bini LM, Murphy KJ (2006) Effect of reservoir drawdown on biomass of three species of aquatic macrophytes in a large sub-tropical reservoir (Itaipu, Brazil). Hydrobiologia 570:53-59

Tolonen KT, Hämäläinen H (2010) Comparison of sampling methods and habitat types for detecting impacts on lake littoral macroinvertebrate assemblages along a gradient of human disturbance. Fundam Appl Limnol Archiv für Hydrobiol 176:43-59

Turner MA, Huebert DB, Findlay DL, Hendzel LL, Jansen WA, Bodaly RA, Armstrong LM, Kasian SEM (2005) Divergent impacts of experimental lake-level drawdown on planktonic and benthic plant communities in a boreal forest lake. Can J Fish Aquat Sci 62:991-1003

Vadeboncoeur Y, Steinman AD (2002) Periphyton function in lake ecosystems. Sci World J 2:1449-1468

Vadeboncoeur Y, Vander Zanden MJ, Lodge DM (2002) Putting the lake back together: reintegrating benthic pathways into lake food web models. Bioscience 52:44-54

Vadeboncoeur Y, Kalff J, Christoffersen K, Jeppesen E (2006) Substratum as a driver of variation in periphyton chlorophyll and productivity in lakes. J N Am Benthol Soc 25:379-392

Vadeboncoeur Y, Peterson G, Vander Zanden MJ, Kalff J (2008) Benthic algal production across lake size gradients: interactions among morphometry, nutrients, and light. Ecology 89:2542-2552

Van Geest GJ, Wolters H, Roozen FCJM, Coops H, Roijackers RMM, Buijse AD, Scheffer M (2005) Water-level fluctuations affect macrophyte richness in floodplain lakes. Hydrobiologia 539:239-248

Van Geest GJ, Coops H, Scheffer M, Van Nes EH (2007) Long transients near the ghost of a stable state in eutrophic shallow lakes with fluctuating water levels. Ecosystems 10:36-46

Vander Zanden MJ, Vadeboncoeur Y, Chandra S (2011) Fish reliance on littoral-benthic resources and the distribution of primary production in lakes. Ecosystems 10:894-903

VANR (1990) The Lake Bomoseen drawdown: an evaluation of its effects on aquatic plants, wildlife, fish, invertebrates, and recreational uses. Vermont Agency of Natural Resources, Waterbury

Verrill DD, Berry CR Jr (1995) Effectiveness of an electric barrier and lake drawdown for reducing common carp and bigmouth buffalo abundances. N Am J Fish Manag 15:137-141

Vuorio K, Järvinen M, Moilanen S, Kotamäki N, Bilaletdin Ä (2015) Water level regulation in winter triggers fouling of fishing nets by the biatom Aulacoseira islandica in a boreal lake. Boreal Environ Res 20:587-602

Wagner T, Falter CM (2002) Response of an aquatic macrophyte community to fluctuating water levels in an oligotrophic lake. Lake Reserv Manag 18:52-65

Wantzen KM, Rothhaupt K-O, Mörtl M, Cantonati M, Tóth LG, Fischer P (2008) Ecological effects of water-level fluctuations in lakes: an urgent issue. Hydrobiologia 613:1-4

Watts CJ (2000) Seasonal phosphorus release from exposed, re-inundated littoral sediments of two Australian reservoirs. Hydrobiologia 431:27-39

Weatherhead MA, James MR (2001) Distribution of macroinvertebrates in relation to physical and biological variables in the littoral zone of nine New Zealand lakes. Hydrobiologia 462:115-129

Wegener W, Williams V (1975) Fish population responses to improved lake habitat utilizing an extreme drawdown. In: Proceedings of the annual conference southeastern association of game and fish commissioners 28:144-161

Werner S, Rothhaupt K-O (2008) Mass mortality of the invasive bivalve Corbicula fluminea induced by a severe low-water event and associated low water temperatures. Hydrobiologia 613:143-150

White MS, Xenopoulos MA, Hogsden K, Metcalfe RA, Dillon PJ (2008) Natural level fluctuation and associated concordance with water quality and aquatic communities within small lakes of the Laurentian Great Lakes region. Hydrobiologia 613:21-31

White MS, Xenopoulos MA, Metcalfe RA, Somers KM (2010) On the role of natural water level fluctuation in structuring littoral benthic macroinvertebrate community composition in lakes. Limnol Oceanogr 55:2275-2284

White MS, Xenopoulos MA, Metcalfe RA, Somers KM (2011) Water level thresholds of benthic macroinvertebrate richness, structure, and function of boreal lake stony littoral habitats. Can J Fish Aquat Sci 68:1695-1704

Wilcox DA, Meeker JE (1991) Disturbance effects on aquatic vegetation in regulated and unregulated lakes in northern Minnesota. Can J Bot 69:1542-1551

Wilcox DA, Meeker JE (1992) Implications for faunal habitat related to altered macrophyte structure in regulated lakes in northern Minnesota. Wetlands 12:192-203

Wilson JS, Baldwin DS (2008) Exploring the "Birch effect' in reservoir sediments: influence of inundation history on aerobic nutrient release. Chem Ecol 24:379-386

Winfield IJ (2004) Fish in the littoral zone: ecology, threats and management. Limnologica 34:124-131

Yamanaka H (2013) Hypoxic conditions enhance refuge effect of macrophyte zone for small prey fish from piscivorous predators. Fish Manag Ecol 20:465-472 
Ziegler JP, Solomon CT, Finney BP, Gregory-Eaves I (2015) Macrophyte biomass predicts food chain length in shallow lakes. Ecosphere 6:5

Ziegler JP, Gregory-Eaves I, Solomon CT (2017) Refuge increases food chain length: modeled impacts of littoral structure in lake food webs. Oikos. doi:10.1111/oik.03517
Zohary T, Ostrovsky I (2011) Ecological impacts of excessive water level fluctuations in stratified freshwater lakes. Inland Waters $1: 47-59$ 